\title{
Microstructure and Corrosion of Cast Magnesium Alloy ZK60 in NaCl Solution
}

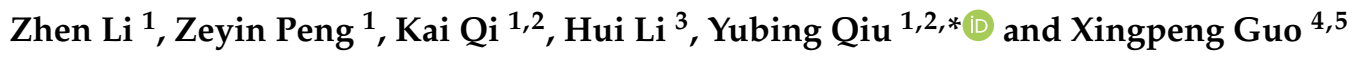 \\ 1 School of Chemistry and Chemical Engineering, Huazhong University of Science and Technology, \\ Wuhan 430074, China; fylz1989@hust.edu.cn (Z.L.); m201770328@hust.edu.cn (Z.P.); \\ qikai@hust.edu.cn (K.Q.) \\ 2 Key Laboratory of Material Chemistry for Energy Conversion and Storage, Huazhong University of Science \\ and Technology, Ministry of Education, Wuhan 430074, China \\ 3 Changqing Oil and Gas Technology Institute, Changqing Oil Field Company, Xi'an 710021, China; \\ lhui2_cq@petrochina.com.cn \\ 4 Hubei Key Laboratory of Materials Chemistry and Service Failure, Wuhan 430074, China; \\ guoxp@mail.hust.edu.cn \\ 5 School of Chemistry and Chemical Engineering, Guangzhou University, Guangzhou 510006, China \\ * Correspondence: qiuyubin@mail.hust.edu.cn; Tel.: +86-13-545-266-622
}

Received: 5 August 2020; Accepted: 27 August 2020; Published: 30 August 2020

check for updates

\begin{abstract}
In this work, the effects of the microstructure and phase constitution of cast magnesium alloy ZK60 (Mg-5.8Zn-0.57Zr, element concentration in wt.\%) on the corrosion behavior in aqueous $\mathrm{NaCl}\left(0.1 \mathrm{~mol} \mathrm{dm}^{-3}\right)$ were investigated by weight-loss measurements, hydrogen evolution tests, and electrochemical techniques. The alloy was found to be composed of $\alpha-\mathrm{Mg}$ matrix, with large second-phase particles of $\mathrm{MgZn}_{2}$ deposited along grain boundaries and a $\mathrm{Zr}$-rich region in the central area of the grains. The large second-phase particles and the $\mathrm{Zr}$-rich regions were more stable than the Mg matrix, resulting in a strong micro-galvanic effect. A filiform corrosion was found. It originated from the second-phase particles in the grain boundary regions in the early corrosion period. The filaments gradually occupied most areas of the alloy surface, and the general corrosion rate decreased significantly. Corrosion pits were developed under filaments. The pit growth rate decreased over time; however, it was about eight times larger than the general corrosion rate. A schematic model is presented to illustrate the corrosion mechanism.
\end{abstract}

Keywords: ZK60 magnesium alloys; microstructure; filiform-like corrosion; corrosion pit

\section{Introduction}

Magnesium (Mg) alloys have been widely applied as lightweight engineering materials due to their unique properties [1-8]. As commercial Mg-Zn-based alloys, ZK60 (Mg-Zn-Zr) alloys [9] have attracted great interest from researchers due to their high strength [10-12]. The microstructure [13,14], mechanical properties [15-17], and biological applications [18,19] of ZK60 alloys have been studied widely in recent decades. It has been verified that microstructure evolution is essential for the mechanical properties of ZK60 alloys, grain refinement, and stable precipitates, having vital effects on improving the mechanical properties [20-23]. Nevertheless, the weak corrosion resistance of ZK60 alloys limits their further applications.

The microstructure of Mg alloys, especially their second phases, has an evident impact on their corrosion behavior [3,5]. The second phases of $\mathrm{Mg}$ alloys may have a dual role in their corrosion, i.e., a galvanic acceleration effect or a corrosion blocking effect, depending on their quantities and distribution [24-26]. In Mg-Al alloys, when the amount of aluminum (Al) is low (e.g., Mg-5Al), the $\beta$-phase $\left(\mathrm{Mg}_{12} \mathrm{Al}_{17}\right)$ is relatively discontinuous in the $\mathrm{Mg}$ matrix and mainly acts as a cathode 
phase to accelerate the dissolution of the matrix. As the content of the $\mathrm{Al}$ element increases (e.g., $\mathrm{Mg}-10 \mathrm{Al})$, the $\beta$-phase precipitates are tiny and continuously distributed along the grain boundaries, producing a barrier to prevent corrosion [27]. The similar effect of the second phase was reported in other Mg alloys [28,29]. However, the effect of the second phase in ZK60 alloys on their corrosion behaviors is barely reported. Some researchers tried to enhance the corrosion resistance of ZK60 alloys by modifying their microstructure through heat treatment [30,31], deformation processing [32], and alloying [33-36]. Even so, the relationship between the microstructure and corrosion behavior of ZK60 alloys needs more studies for it to be investigated.

Some studies reported the corrosion behavior of ZK60 alloys on different occasions. Cheng et al. [37] pointed out that the Zr element in ZK60 alloys refined the grain and purified the alloy composition, which could improve its corrosion resistance in $1 \mathrm{M} \mathrm{NaCl}$. Zeng et al. [38] investigated the effects of the microstructure and concentration of $\mathrm{NaCl}$ (3.5 and $5.0 \mathrm{wt} . \%$ ) on the corrosion behavior of an extruded ZK60 alloy. They found that an increase in the grain size of the ZK60 alloy accelerated its corrosion rate. The alloy microstructure played a crucial role in the pitting and intergranular corrosion. $\mathrm{Xu}$ et al. [39] reported that the corrosion rate of a cast ZK60 alloy decreased with the immersion time in solutions containing $3.5 \mathrm{wt} . \% \mathrm{NaCl}, \mathrm{NaBr}$, and $\mathrm{NaI}$, while it displayed passivation in $3.5 \mathrm{wt} . \% \mathrm{NaF}$ solution. Apart from the above reports, some studies focused on the biodegradation behavior of ZK60 alloys in Hank's solution, Ringer's solution, simulated body fluid, and artificial urine for biomedical applications [40-43]. The biodegradable property of the ZK60 alloys is the interesting issue in these investigations. In general, the above research usually concentrated on the uniform corrosion of ZK60 alloys, and little attention was paid to the development of their local corrosion. The influence of microstructure on the local corrosion of ZK60 alloys is still not clearly understood, especially the effect of the second phase.

In this study, a commercial cast ZK60 alloy was selected as the test material. Its microstructure was characterized by X-ray diffraction (XRD), scanning electron microscopy (SEM), energy-dispersive X-ray spectroscopy (EDX), and scanning Kelvin probe force microscopy (SKPFM) analysis. The general and local corrosion of the alloy in $0.1 \mathrm{M} \mathrm{NaCl}$ was investigated using weight loss tests, hydrogen evolution tests, and electrochemical measurements, as well as corrosion morphology monitoring with an optical microscope and SEM. The effect of the microstructure of the cast ZK60 alloy, especially the second phase and the distribution of alloying elements, on the corrosion initiation and developmental features of the alloy were investigated, and the mechanisms involved were studied. This work will help to verify the relationship between the microstructure and the corrosion behavior of ZK60 alloys. Moreover, it may also provide a theoretical basis for improving the corrosion resistance of ZK60 alloys by adjusting the microstructure in future research.

\section{Materials and Methods}

\subsection{Test Material and Solution}

A commercial as-cast ZK60 alloy was used in this study. Table 1 presents its chemical composition, analyzed by inductively coupled plasma-atomic emission spectrometry (ICP-AES, SPECTRO, Kleve, Germany). All the solutions used in this work were prepared with analytical-grade reagents and distilled water. The test solution was $0.1 \mathrm{M} \mathrm{NaCl}$ under an open-air condition, which was controlled at $25 \pm 1{ }^{\circ} \mathrm{C}$ with a water bath.

Table 1. Chemical composition of the cast ZK60 alloy (wt.\%).

\begin{tabular}{ccccccc}
\hline Zn & Al & Fe & Ni & Cu & Zr & Mg \\
\hline 5.80 & $<0.01$ & $<0.01$ & $<0.01$ & $<0.01$ & 0.57 & Bal. \\
\hline
\end{tabular}




\subsection{Microstructure Characterization}

The cast ZK60 samples $\left(10 \times 10 \times 10 \mathrm{~mm}^{3}\right)$ were sealed with epoxy resin (working area $\left.=1.0 \mathrm{~cm}^{2}\right)$, ground with 2000 grit SiC paper, and polished with $3 \mu \mathrm{m}$ diamond paste. Then, they were etched with a picric acid solution for metallographic analysis. The metallographic structure of the cast ZK60 sample was observed using a 3D optical microscope (VHX-1000, KEYENCE, Osaka, Japan), SEM (Quanta 200, FEI, Eindhoven, The Netherlands) equipped with EDX (EDAX-Genesis), and transmission electron microscopy (TEM). The TEM sample was firstly mechanically ground to a thickness of about $20 \mu \mathrm{m}$, and then, it was ion milled at $4 \mathrm{keV}$ and $4^{\circ}$, cooled by liquid nitrogen. TEM observations were carried out with an FEI Talos F200X transmission electron microscope (FEI, Portland, OR, USA) operated at $200 \mathrm{kV}$. The element content and elemental distribution of the cast ZK60 sample were characterized by EDX and an electron probe micro-analyzer (EPMA-8050G, SHIMADZU, Kyoto, Japan), respectively. Phase structure analysis was performed by XRD (X'Pert PRO, PANalytical B.V., Almelo, The Netherlands) using $\mathrm{Cu} \mathrm{K} \alpha$ radiation. The scan range of $2 \theta$ was from $20^{\circ}$ to $90^{\circ}$ with a scan step of $0.02^{\circ}$. The XRD pattern was analyzed with the X'Pert HighScore Plus software (2.0, PANalytical B.V., Almelo, The Netherlands). SKPFM (SPM-9700, SHIMADZU, Kyoto, Japan) was used to measure the relative Volta potential differences among different microstructural constituents to show their relative nobility. Meanwhile, the corresponding topography maps of the same area were also obtained.

\subsection{Electrochemical Tests}

All the electrochemical tests were carried out using a CS 350 Corrtest electrochemical workstation (Wuhan Corrtest, Wuhan, China). The working electrode $\left(10 \times 10 \times 10 \mathrm{~mm}^{3}\right)$ was sealed with epoxy resin (working area $=1.0 \mathrm{~cm}^{2}$ ), which was ground with 2000 grit SiC paper and rinsed in distilled water and ethanol. A saturated calomel electrode (SCE) and a platinum (Pt) electrode were used as the reference electrode and the counter electrode, respectively. Polarisation curves were generated and electrochemical impedance spectroscopy (EIS) was performed, respectively, at different corrosion times. At free corrosion potentials ( $E_{\text {corr }}$ ), the EIS tests were performed with an AC voltage amplitude of $10 \mathrm{mV}$ in the frequency range of $100 \mathrm{kHz}-0.05 \mathrm{~Hz}$. The EIS results were fitted with the Zview2.0 software. The polarization curves were generated at the scan rate of $0.5 \mathrm{mV} \mathrm{s}^{-1}$, scanning towards the positive direction. The corrosion current density $\left(i_{\mathrm{corr}}, \mathrm{mA} \mathrm{cm}^{-2}\right)$ was estimated by the cathodic Tafel extrapolation method, according to $[5,44]$. The corresponding corrosion rate $\left(P_{\mathrm{i}}, \mathrm{mm} \mathrm{y}^{-1}\right)$ was converted by the equation $[5,45]$ :

$$
P_{\mathrm{i}}=22.06 i_{\text {corr }}
$$

where the corrosion current density $i_{\text {corr }}$ is estimated by the Tafel extrapolation of the cathodic branch of the polarization curves, and $P_{\mathrm{i}}$ is related to the average corrosion rate.

All the electrochemical tests were repeated at least three times in this study.

\subsection{Weight Loss Tests}

The cast ZK60 specimens $\left(20 \times 20 \times 4 \mathrm{~mm}^{3}\right)$ were ground with 2000 grit SiC paper, rinsed in distilled water and ethanol, dried with cold air, and kept in a vacuum desiccator before the weight loss test. The specimens were corroded in $0.1 \mathrm{M} \mathrm{NaCl}$ for different times and then immersed in a $\mathrm{CrO}_{3}$ solution $\left(180 \mathrm{~g} \mathrm{~L}^{-1}, \sim 25^{\circ} \mathrm{C}\right)$ for $10 \mathrm{~min}$ to remove corrosion products. At least three parallel tests were performed under each test condition. The average weight loss rate of the cast ZK60 alloy $(\Delta W$, $\mathrm{mg} \mathrm{cm} \mathrm{ch}^{-2} \mathrm{~h}^{-1}$ can be converted to a general corrosion rate $\mathrm{P}_{\mathrm{w}}\left(\mathrm{mm} \mathrm{y}^{-1}\right)$ using $[5,44]$ :

$$
P_{\mathrm{w}}=3.6524 \Delta W / \rho
$$

where $\rho$ is the metal density $\left(\mathrm{g} \mathrm{cm}^{-3}\right)$. For the cast ZK60 alloy, $\rho=1.8 \mathrm{~g} \mathrm{~cm}^{-3}$; thus, Equation (2) becomes:

$$
P_{\mathrm{w}}=48.67 \Delta W
$$




\subsection{Hydrogen Evolution Tests}

Following the work of Shi [46], plug-in specimens were employed to perform the hydrogen evolution test in $0.1 \mathrm{M} \mathrm{NaCl}$ at room temperature $\left(\sim 25^{\circ} \mathrm{C}\right)$. Figure 1 presents the schematics of the test system. The cast ZK60 specimens $\left(10 \times 10 \times 10 \mathrm{~mm}^{3}\right)$ were treated as the above weight loss samples. The evolved hydrogen was collected into a burette, and its volume $\left(V_{\mathrm{H}}, \mathrm{mL} \mathrm{cm}^{-2}\right)$ was recorded at different times. The hydrogen evolution rate, $\mathrm{v}_{\mathrm{H}}\left(\mathrm{mL} \cdot \mathrm{cm}^{-2}\right.$ day $\left.{ }^{-1}\right)$, can also be converted to a general corrosion rate, $P_{\mathrm{H}}\left(\mathrm{mm} \mathrm{y}^{-1}\right)$, using [5,44].

$$
P_{\mathrm{H}}=2.2 v_{\mathrm{H}}
$$

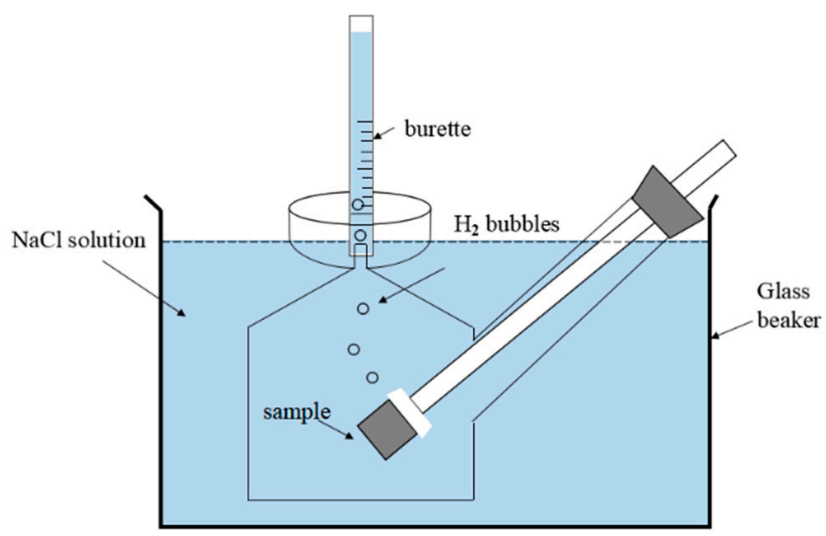

Figure 1. Schematic diagram of the test system for the hydrogen evolution measurement.

\subsection{Corrosion Morphology Characterization}

The etched metallographic specimens were placed in $0.1 \mathrm{M} \mathrm{NaCl}$, where the solution thickness on the sample surface was about $1 \mathrm{~mm}$, to observe the corrosion development in the initial period $(0-1 \mathrm{~h})$ in situ using a 3D optical microscope (KEYENCE VHX-1000). The corrosion morphologies of the cast ZK60 samples corroded in $0.1 \mathrm{M} \mathrm{NaCl}$ for different times were measured by SEM and with the 3D optical microscope. The cross-section corrosion morphologies and the elemental distributions were analyzed by EPMA (EPMA-8050G).

\section{Results and Discussion}

\subsection{Microstructure of the Cast ZK60 Alloy}

Figure 2 shows the optical and the back-scattered electron (BSE) SEM micrographs of the cast ZK60 alloy. The microstructure of the cast ZK60 alloy was composed of an $\alpha$-Mg phase and large second-phase particles, which were mainly deposited along the grain boundaries (Figure 2a,b). According to [47,48], the main components of these particles are $\mathrm{Mg}$ and $\mathrm{Zn}$ and may be $\mathrm{MgZn}_{2}$ and $\mathrm{MgZn}$. The XRD pattern of the cast ZK60 alloy in Figure 3 only displays the presence of $\mathrm{MgZn}_{2}$. No discernable diffraction peaks from MgZn were detected in this work, which suggests no MgZn phase in the studied alloy; also, there is no $\mathrm{Zr}$ detected, maybe due to its low content in the test sample. However, the XRD patterns cannot give accurate structural information for the second phase. Therefore, the crystal structures of the abovementioned second phases were characterized using TEM in detail as follows.

To further verify the second phase in the as-cast ZK60 alloy, Figure 4 presents the TEM micrograph of the as-cast ZK60 alloy. Block-shaped and globular second-phase particles can be observed in Figure 4 . The blocky phase has a size of about $500 \mathrm{~nm}$, and the globular phase is about $100 \mathrm{~nm}$. Figure 4 also presents the corresponding selected area electron diffraction (SAED) patterns of the second phase. The SAED patterns proved that the two second-phase particles were $M g Z n_{2}$ [49]. No MgZn phase was found in the as-cast ZK60 alloy. 

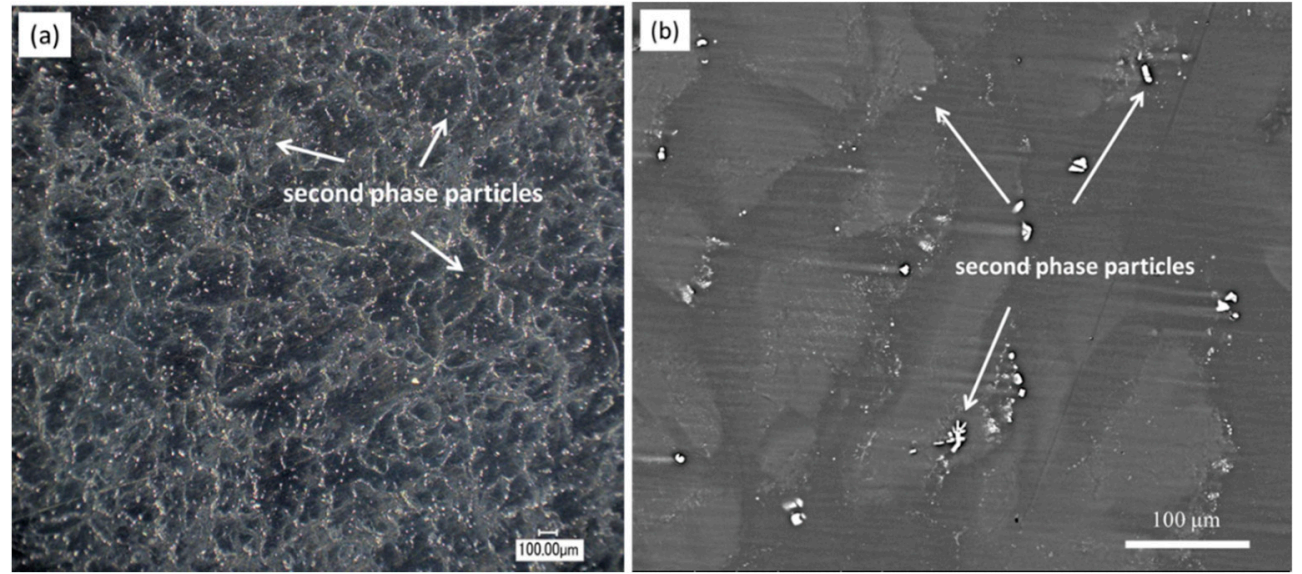

Figure 2. (a) Optical and (b) BSE-SEM micrographs of the cast ZK60 alloy.

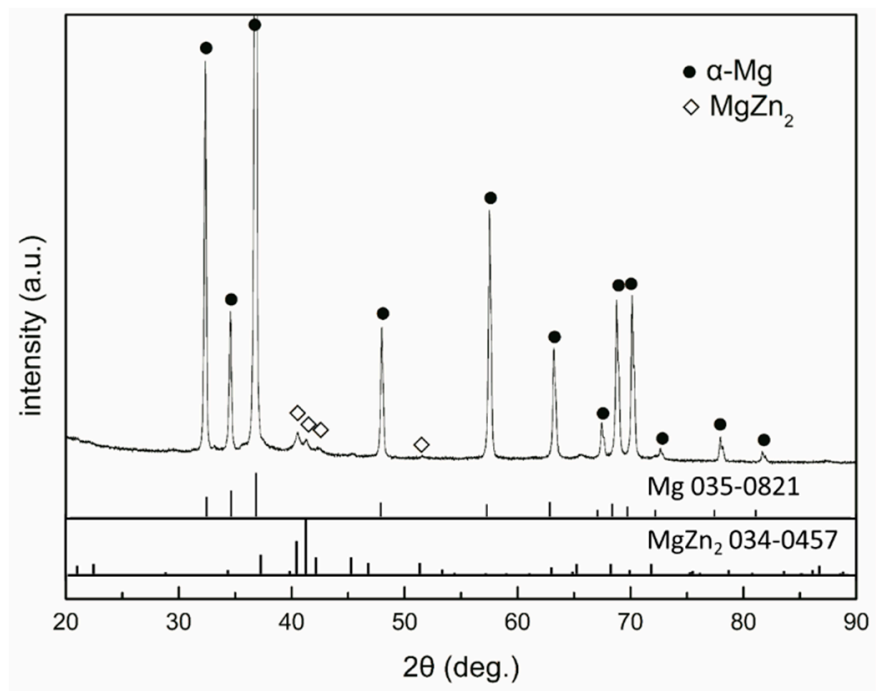

Figure 3. XRD pattern of the cast ZK60 alloy.

The BSE-SEM micrograph in Figure $2 \mathrm{~b}$ indicates the nonuniform distribution of the alloying elements in the cast ZK60 because the brighter areas contain more elements of higher atomic weight than the darker regions [50]. Figure 5 presents the area distribution of the alloying elements in the cast ZK60, proving that the center area of the grains with light color was richer in $\mathrm{Zr}$ and $\mathrm{Zn}$ (Zr-rich region) than the neighboring darker zones (grain boundary region). Here, the "grain boundary region" of the as-cast ZK60 is denoted as the areas between the Zr-rich region, i.e., the dark areas in Figure 2b. This uneven distribution of the alloying elements in the cast ZK60 alloy may cause the inhomogeneous electrochemical activity resulting in the micro-galvanic corrosion [51].

Figure 6 presents the SKPFM maps of the cast ZK60 sample, which clearly show that the second phase had the highest potential. Furthermore, the Volta potential profiles (Figure 6c) along the line A and line $\mathrm{B}$ indicated that the central region of the grains (i.e., $\mathrm{Zr}$-rich region) exhibited higher potential than those of the grain boundary regions, owing to the higher $\mathrm{Zr}$ and $\mathrm{Zn}$ contents in the center of grains and higher $\mathrm{Mg}$ content in the grain boundary regions (Figure 5). Thus, the second-phase particles and the central region of the grains should be more stable than the $\mathrm{Mg}$ matrix in grain boundary regions and more likely to become cathodes in the micro-galvanic cells. A second-phase particle occurred in the grain area (Figure 6a), which is consistent with Figure 2a, so the micro-galvanic corrosion may also have been initiated in the grains. 

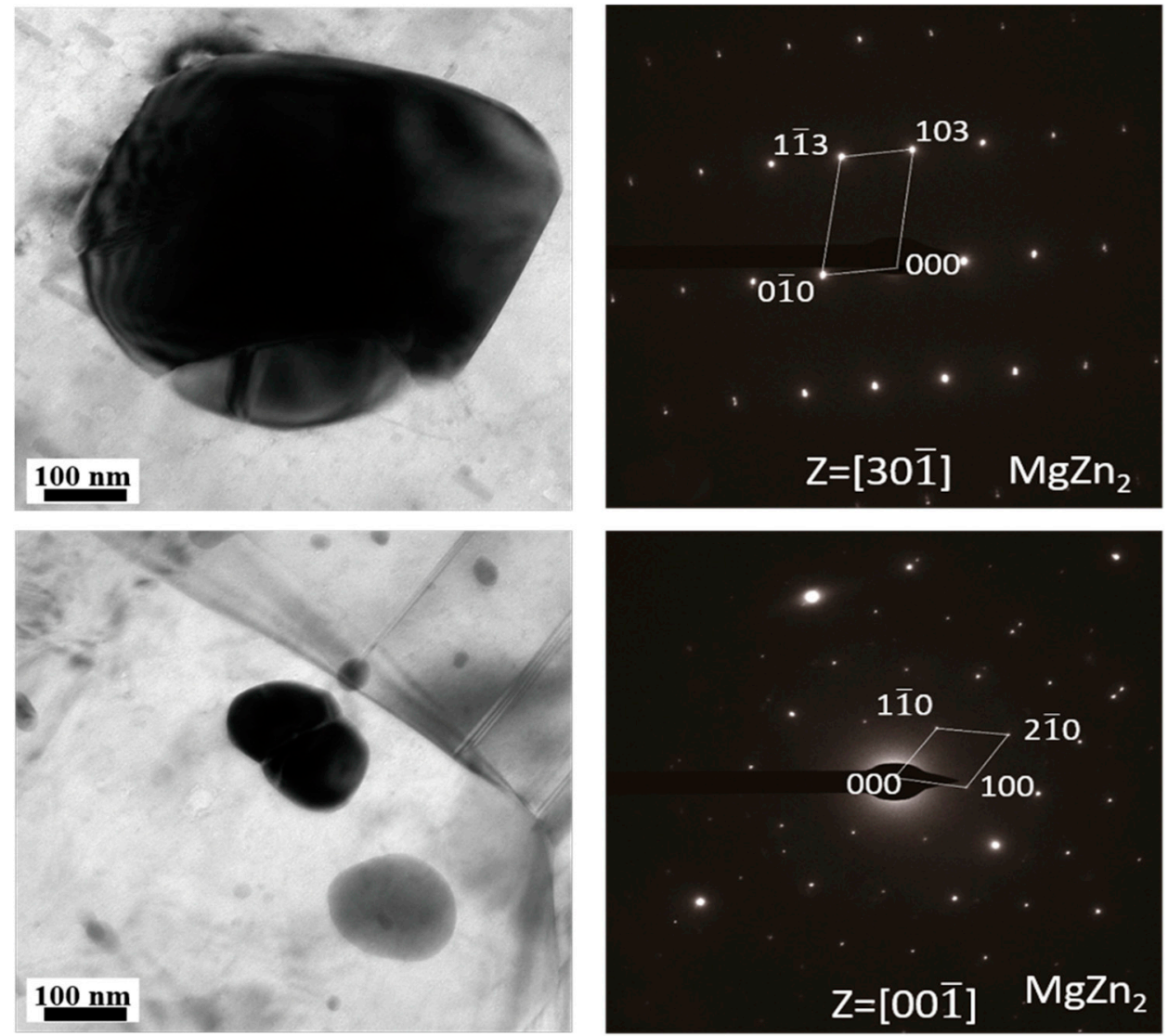

Figure 4. TEM micrograph of the cast ZK60 alloy and the corresponding selected area electron diffraction (SAED) patterns of the second-phase particles.
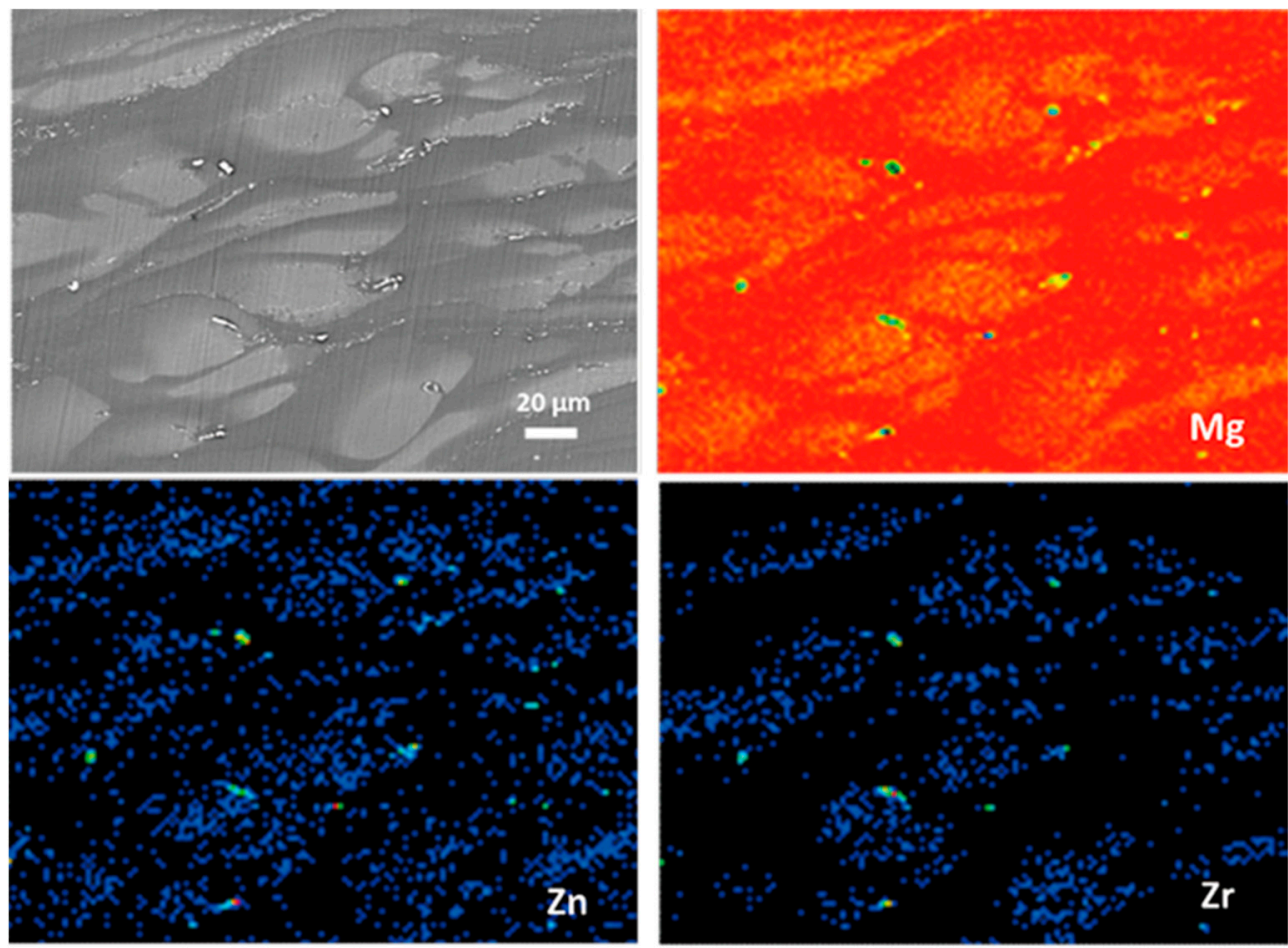

Figure 5. BSE-SEM image of the cast ZK60 alloy and the corresponding area distributions of $\mathrm{Mg}, \mathrm{Zn}$, and $\mathrm{Zr}$. 

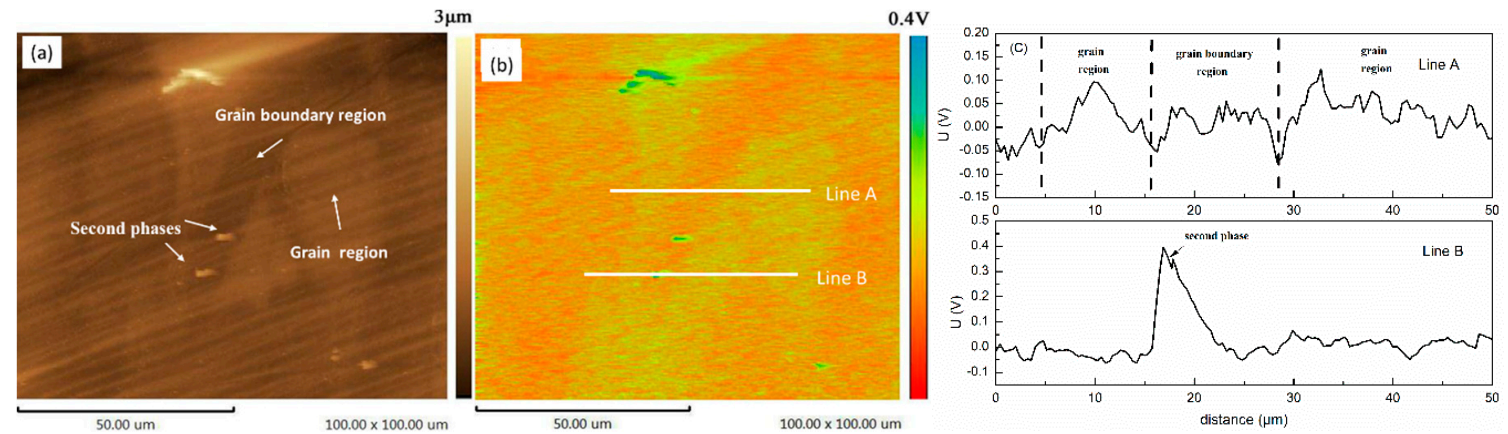

Figure 6. (a) Scanning Kelvin probe force microscopy (SKPFM) topography map; (b) Potential map of the same area; (c) Volta potential profiles along lines A and B in the SKPFM image.

\subsection{Weight Loss Tests}

Figure 7 shows the $\Delta W\left(\mathrm{mg} \mathrm{cm}^{-2} \mathrm{~h}^{-1}\right)$ and $P_{\mathrm{w}}\left(\mathrm{mm} \mathrm{y}^{-1}\right)$ values of the cast ZK60 alloy immersed in $0.1 \mathrm{M} \mathrm{NaCl}$ for different times $(\mathrm{t})$. The $P_{\mathrm{w}}$ at $24 \mathrm{~h}$ was the largest $\left(3.5 \pm 0.1 \mathrm{~mm} \mathrm{y}^{-1}\right)$, which is similar to that of a cast ZK60 in $0.9 \% \mathrm{NaCl}\left(4.6 \pm 0.6 \mathrm{~mm} \mathrm{y}^{-1}\right)$ reported by Merson et al. [52]. Then, it gradually decreased by approximately half to a relatively stable value $\left(1.4 \sim 1.7 \mathrm{~mm} \mathrm{y}^{-1}\right)$ over $72-96 \mathrm{~h}$. The decrease in $P_{\mathrm{w}}$ over $72-96 \mathrm{~h}$ may have been related to the increase in the corrosion product layer $\mathrm{Mg}(\mathrm{OH})_{2}$ on its surface [53].

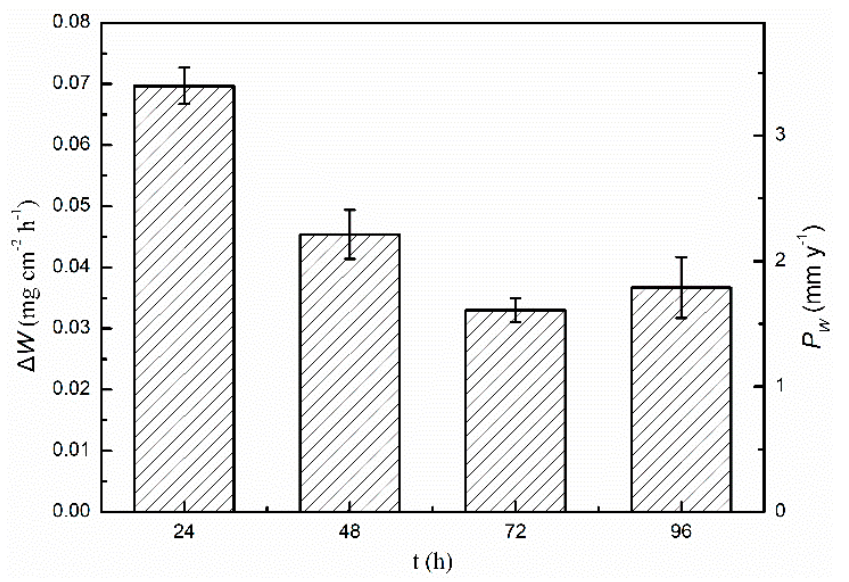

Figure 7. Corrosion rates $\left(\Delta W\right.$ and $\left.P_{\mathrm{W}}\right)$ of the cast ZK60 alloy after immersion in $0.1 \mathrm{M} \mathrm{NaCl}$ for different times measured by weight loss tests.

\subsection{Hydrogen Evolution Tests}

Figure 8 presents the hydrogen evolution test results for the cast ZK60 alloy to show the change in its corrosion rate in detail, in which $v_{\mathrm{H}}$ is the differentiation of the $V_{\mathrm{H}}$-t curve in Figure $8 \mathrm{a}$ and $P_{\mathrm{H}}$ is calculated by Equation (4). The $V_{\mathrm{H}}$ at $24 \mathrm{~h}$ (Figure $8 \mathrm{a}$ ) was about $0.7 \pm 0.03 \mathrm{~mL} \mathrm{~cm}^{-2}$, which is higher than that of an extruded ZK60 $\left(\sim 0.5 \mathrm{~mL} \mathrm{~cm}^{-2}\right)$ [54]. The $P_{\mathrm{H}}$ value (Figure $\left.8 \mathrm{~b}\right)$ increased with time in the initial corrosion period $(0-1.5 \mathrm{~h})$ and then decreased over $1.5-48 \mathrm{~h}$; at last, it increased again over 48-72 $\mathrm{h}$. These results imply that there exist different corrosion stages in the periods of $0-2 \mathrm{~h}, 2-48 \mathrm{~h}$, and 48-72 h, which may be related to the change in the alloy surface condition. According to Song [24], the total volume of hydrogen collected should equal the total amount of metal lost, and both the weight loss and hydrogen evolution tests were reliable methods. Even though the hydrogen evolution rate $P_{\mathrm{H}}$ we measured is slightly lower than the weight loss corrosion rate $P_{\mathrm{w}}$, which may be caused by the difference in the test methods, they generally show similar change tendencies. 

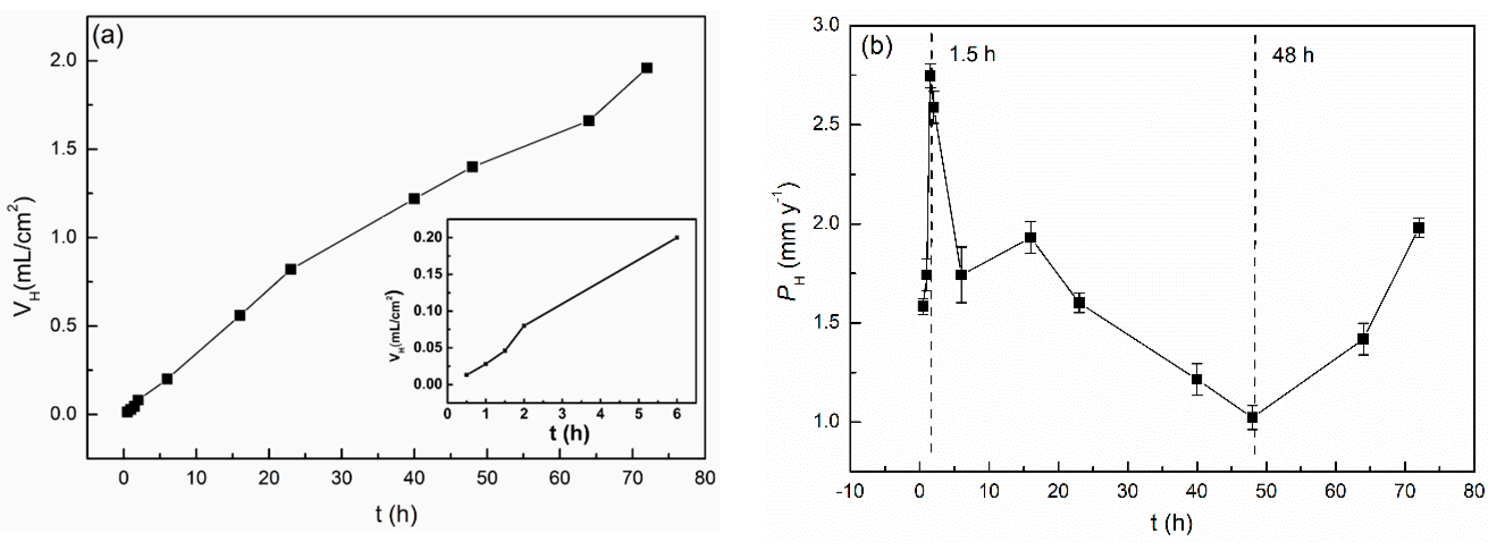

Figure 8. Changes in (a) $V_{\mathrm{H}}$ and (b) $P_{\mathrm{H}}$ of the cast $\mathrm{ZK} 60$ alloy as a function of time measured by the hydrogen evolution test in $0.1 \mathrm{M} \mathrm{NaCl}$.

\subsection{Polarisation Curve Measurements}

Figure 9 presents the polarization curves of the cast ZK60 alloy after immersion in $0.1 \mathrm{M} \mathrm{NaCl}$ for different times and the changes in its corrosion rates $\left(\mathrm{i}_{\text {corr }}\right.$ and $\left.\mathrm{P}_{\mathrm{i}}\right)$ with time. All the polarization curves showed the typical features of activation-controlled processes [55,56]. A so-called breakdown potential ( $E_{\text {break }}$ ) occurred in the anodic polarization curves (except $t=2 h$ ), owing to the breakdown of the oxide film on the alloy [57], as shown in Figure 9b. $E_{\text {corr }}$ (Figure 9a) and $E_{\text {break }}$ (Figure 9) moved positively in the period of $0-24 \mathrm{~h}$ and then became negative again, while $P_{i}$ and $i_{\text {corr }}$ (Figure $9 b$ ) displayed a similar change with corrosion time to that of $\mathrm{P}_{\mathrm{H}}$ as shown in Figure $8 \mathbf{b}$, which is consistent with previous reports [38,58]. The $i_{\text {corr }}$ and $P_{i}$ values in Figure $9 b$ are much smaller than the $P_{w}$ (Figure 7) and $P_{H}$ (Figure 8b) values. Similar results from other Mg alloys have been discussed in detail in [44]. However, they displayed a similar change tendency. All these results also suggest that there may be different corrosion stages in the corrosion periods of $0-2 \mathrm{~h}, 2-24 \mathrm{~h}$, and $24-72 \mathrm{~h}$.
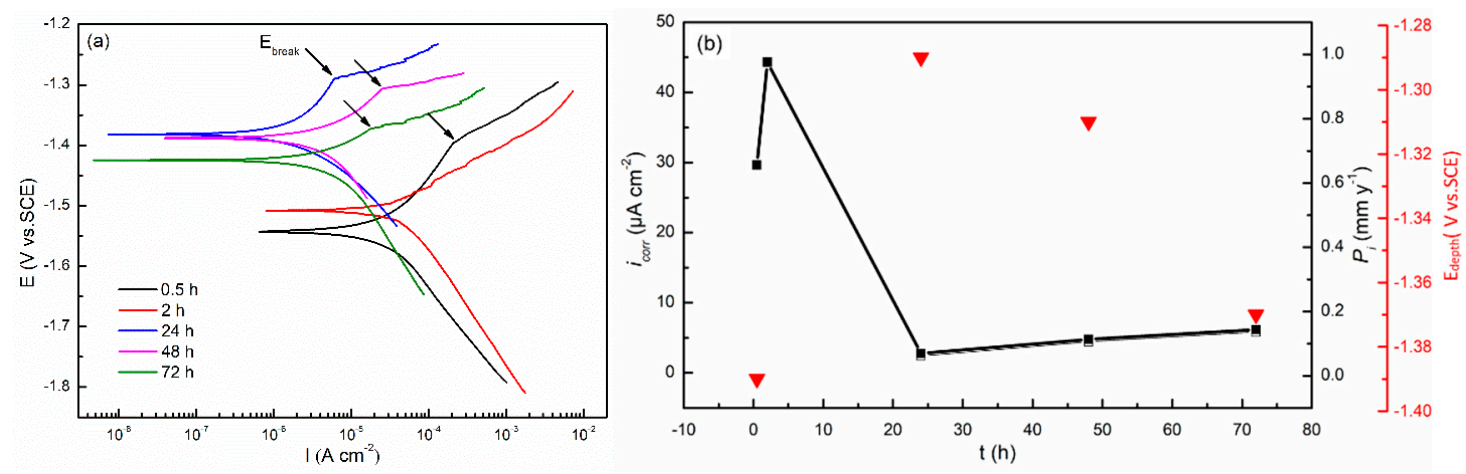

Figure 9. (a) Polarization curves of the cast ZK60 alloy immersed in $0.1 \mathrm{M} \mathrm{NaCl}$ for different times; (b) Changes in the $\mathrm{i}_{\text {corr }}, \mathrm{P}_{\mathrm{i}}$, and $\mathrm{E}_{\text {break }}$ with time $\left(25^{\circ} \mathrm{C}\right)$.

\subsection{EIS Measurements}

Figure 10 presents the EIS of the cast ZK60 alloy immersed in $0.1 \mathrm{M} \mathrm{NaCl}$ for different times and the change in $R_{\mathrm{p}}$ (polarization resistance) as a function of time. All the Nyquist plots display two capacitive loops in the high-frequency region and an inductive loop in the low-frequency region, which is similar to the EIS features of other Mg alloys [59]. The capacitive loops are related to the processes in the surface film and the electrical double layer [60], and the inductive loop should be attributed to the initiation of the localized corrosion on the surface of the cast ZK60 alloy according to [61-63]. Based on these EIS features, Figure 11 presents an equivalent circuit to fit the EIS results in Figure 10a $[58,59,64,65] . R_{\mathrm{s}}$ is the solution resistance. $\mathrm{CPE}_{\mathrm{f}}$ and $\mathrm{CPE}_{\mathrm{dl}}$ represent the constant phase 
elements (CPE) for the surface film and the electrical double layer, respectively. $R_{\mathrm{f}}$ and $R_{\mathrm{ct}}$ represent the surface film resistance and charge-transfer resistance, respectively. $R_{\mathrm{L}}$ and $L$ represent equivalent resistance and inductance to describe the low-frequency inductance. It should be noted that $R_{\mathrm{ct}}$ is the parallel of the charge-transfer resistance of the anodic process and the cathodic process $\left(R_{\mathrm{ct}, \mathrm{a}}\right.$ and $\left.R_{\mathrm{ct}, \mathrm{c}}\right)$ at $E_{\text {corr }}$ [63]. The fitting curves are also displayed in Figure 10a, and the fitting parameters are listed in Table 2.
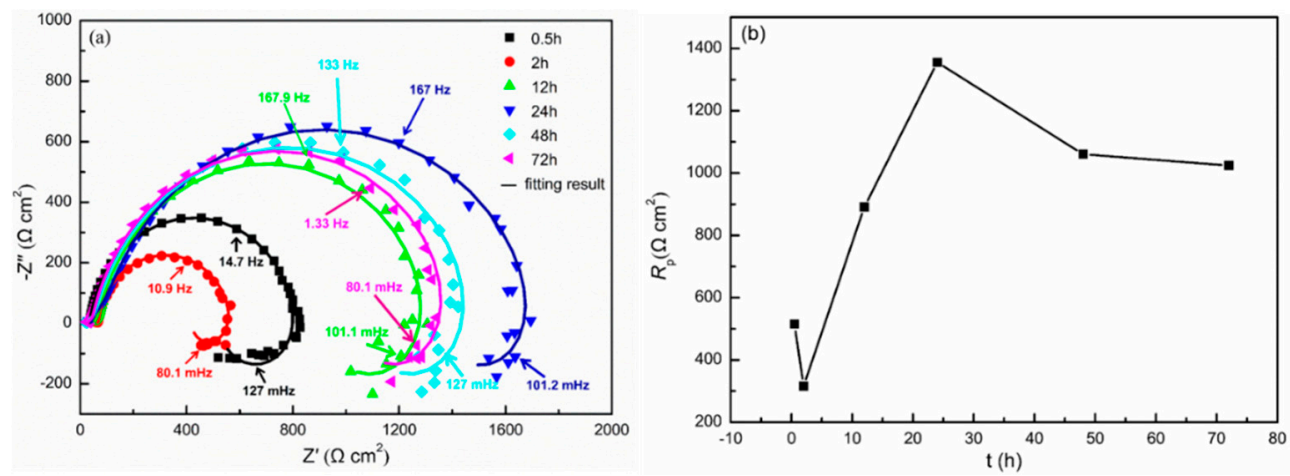

Figure 10. (a) Nyquist plots measured at $E_{\text {corr }}$ for the cast ZK60 alloy immersed in $0.1 \mathrm{M} \mathrm{NaCl}$ for different times; (b) $R_{\mathrm{p}}$-t curves at $25^{\circ} \mathrm{C}$.

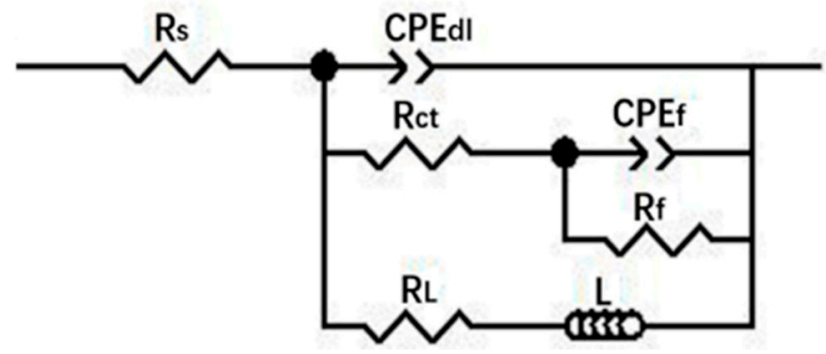

Figure 11. Equivalent circuit used to model the electrochemical impedance spectroscopy (EIS) response of the cast ZK60 alloy in $0.1 \mathrm{M} \mathrm{NaCl}$.

Table 2. Fitting parameters of the EIS results in Figure 9a.

\begin{tabular}{|c|c|c|c|c|c|c|c|c|c|c|}
\hline$\underset{h}{T}$ & $\begin{array}{c}R_{\mathrm{s}} \\
\Omega \cdot \mathrm{cm}^{2}\end{array}$ & $\begin{array}{c}R_{\mathrm{ct}} \\
\Omega \cdot \mathrm{cm}^{2}\end{array}$ & $\begin{array}{c}\mathrm{CPE}_{\mathrm{dl}}-\mathrm{T} \\
\mu \mathrm{Fcm}^{-2} \mathrm{~Hz}^{1-\mathrm{n} 1}\end{array}$ & $\begin{array}{c}C P E_{\mathrm{d} 1}-P \\
n 1\end{array}$ & $\begin{array}{c}R_{\mathrm{f}} \\
\Omega \cdot \mathrm{cm}^{2}\end{array}$ & $\begin{array}{c}\mathrm{CPE}_{\mathrm{f}}-\mathrm{T} \\
\mu \mathrm{Fcm}^{-2} \mathrm{~Hz}^{1-n 2}\end{array}$ & $\begin{array}{c}C P E_{f}-P \\
n 2\end{array}$ & $\begin{array}{c}R_{\mathrm{L}} \\
\Omega \cdot \mathrm{cm}^{2}\end{array}$ & $\begin{array}{c}L \\
H \cdot \mathrm{cm}^{2}\end{array}$ & $\begin{array}{c}\text { Chi-Squared } \\
\text { Error }\end{array}$ \\
\hline 0.5 & 32 & 26 & 22 & 0.87 & 759 & 16 & 0.69 & 1360 & 2359 & $1.55 \times 10^{-2}$ \\
\hline 2 & 65 & 14 & 67 & 0.87 & 502 & 21 & 0.96 & 1224 & 1143 & $1.02 \times 10^{-2}$ \\
\hline 12 & 47 & 37 & 26 & 0.85 & 1254 & 50 & 0.89 & 2686 & 8005 & $1.33 \times 10^{-2}$ \\
\hline 24 & 40 & 179 & 38 & 0.79 & 1546 & 22 & 0.88 & 5865 & 16,588 & $1.23 \times 10^{-2}$ \\
\hline 48 & 27 & 58 & 37 & 0.81 & 1453 & 48 & 0.87 & 3429 & 9781 & $1.48 \times 10^{-2}$ \\
\hline 72 & 28 & 34 & 38 & 0.83 & 1390 & 59 & 0.88 & 3557 & 9029 & $1.67 \times 10^{-2}$ \\
\hline
\end{tabular}

According to $[59,66,67]$ and the results in Table 2, the fitting curves can be extrapolated to the zero-frequency limit to obtain the polarization resistance $\left(R_{\mathrm{p}}\right)$ at different times. Therefore, the $R_{\mathrm{p}}-\mathrm{t}$ curve was obtained as shown in Figure 10b. $R_{\mathrm{p}}$ decreased with time over $0-2 \mathrm{~h}$, indicating corrosion acceleration, and then, $R_{\mathrm{p}}$ clearly increased between 2 and $24 \mathrm{~h}$ before decreasing slightly over $24-72 \mathrm{~h}$. In this case, the change in $R_{\mathrm{p}}$ with $t$ is consistent with that of $P_{\mathrm{i}}$ (Figure $9 \mathrm{~b}$ ). The $R_{\mathrm{t}}$ and $R_{\mathrm{f}}$ values in Table 2 show the same change tendencies as those for $R_{\mathrm{p}}$. The change in the $\mathrm{CPE}_{\mathrm{dl}}, \mathrm{CPE}_{\mathrm{f}}, R_{\mathrm{L}}$, and $\mathrm{L}$ with $t$ should be closely related to the surface layer of the cast ZK60 alloy [59]. The specific changes in these EIS results are discussed later. 


\subsection{Corrosion Morphology of the Cast ZK60 Alloy}

To observe the real-time corrosion development in the initial period $(0-1 \mathrm{~h})$, Figure 12 presents the in situ corrosion images of the etched sample after immersion in $0.1 \mathrm{M} \mathrm{NaCl}$ for different times. In the initial period (20 min, Figure 12a), there was no apparent corrosion, with a limited number of $\mathrm{H}_{2}$ bubbles observed on the surface, implying a slight corrosion state. This slight corrosion should be related to the protective film on the alloy surface impeding the corrosion in the initial period [68]. Over 40-60 min (Figure 12b,c), some dark threads appeared on the surface, which lengthened with time and displayed filiform-like corrosion characteristics. In this period, $\mathrm{H}_{2}$ bubbles constantly evolved at or near the leading edges of the dark threads, leaving cloudy trails behind them. The magnified picture in Figure 12d suggests that the corrosion filaments seem to traverse within the grain boundary regions and do not extend toward the center of the grains in the initial stage of expansion, which is further verified later. These corrosion characteristics are consistent with those of other $\mathrm{Mg}$ alloys in similar corrosion media and should be related to their microstructure features $[50,65,69]$.
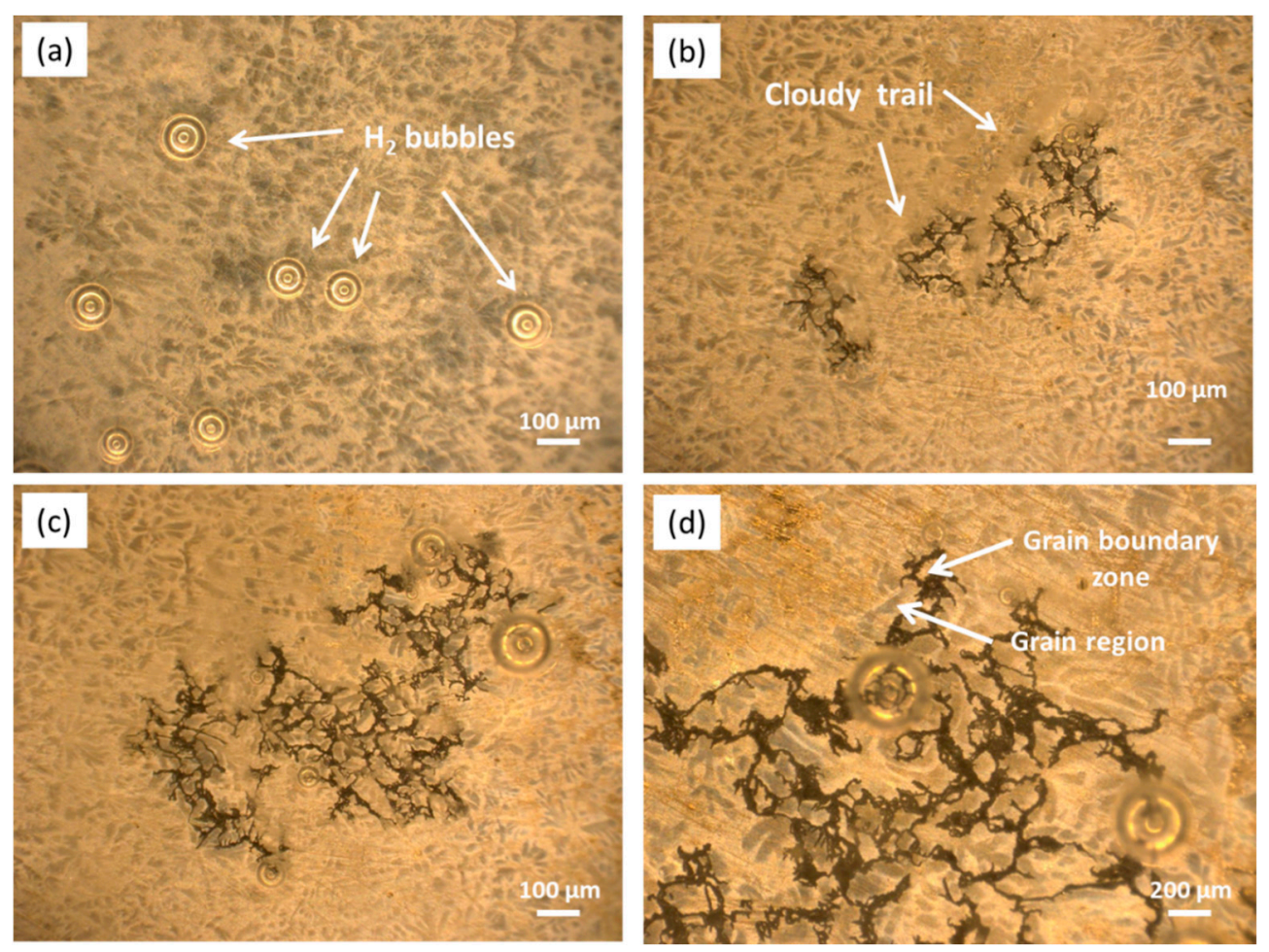

Figure 12. Optical in situ corrosion images of the cast ZK60 etched sample immersed in $0.1 \mathrm{M} \mathrm{NaCl}$ for different times: (a) $20 \mathrm{~min}$; (b) $40 \mathrm{~min}$; (c,d) $60 \mathrm{~min}$.

Figure 13 presents the BSE-SEM micrographs of the etched samples after immersion in $0.1 \mathrm{M}$ $\mathrm{NaCl}$ for 1 and $2 \mathrm{~h}$. The black corrosion filaments (Figure 13a) covered by $\mathrm{Mg}(\mathrm{OH})_{2}$ [70] mainly occurred on the "darker zones" in grain boundary regions (see Figures $2 b$ and 5 ) and encompassed the second-phase particles. Some second-phase particles in the boundary regions (Figure 13b) were surrounded by a small number of black corrosion products, implying that the corrosion filaments may have started from the surrounding areas of these second-phase particles. Most of the central regions of the grains, i.e., the $\mathrm{Zr}$-rich areas with a light color (Figures $2 \mathrm{~b}$ and 5), were still uncorroded. When $t=2 \mathrm{~h}$ (Figure 13c), only a small number of second-phase particles occurred in the corroded areas, implying that most of them were removed due to the dissolution of their surrounding $\mathrm{Mg}$ matrix. Some broad corrosion areas in Figure 13 show that the corrosion could develop to the central area of grains with increasing corrosion time. Moreover, the corrosion filaments in Figure 13c,d show 
an apparent corrosion depth, implying that the corrosion also developed under the black corrosion product layer.
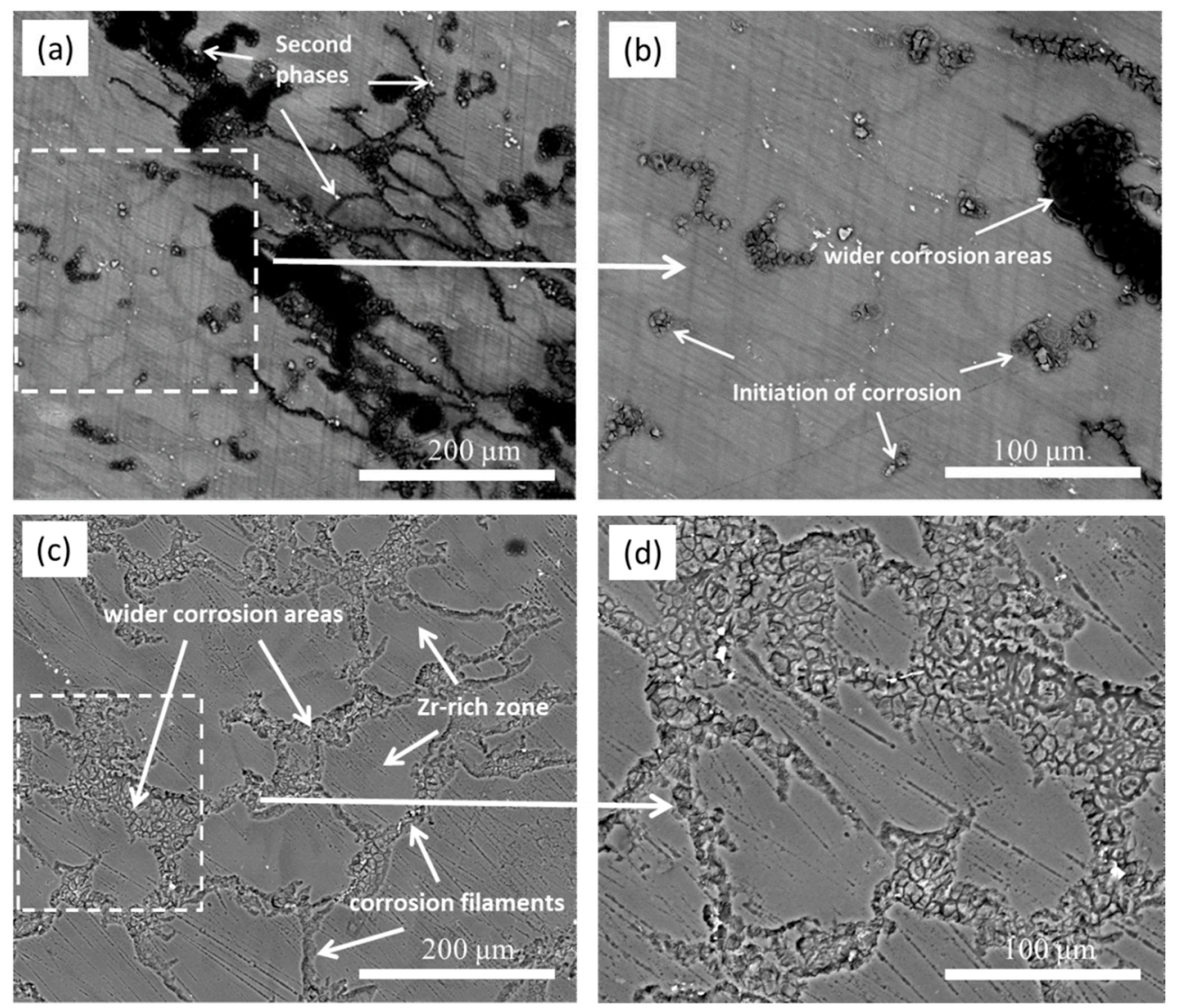

Figure 13. BSE-SEM micrographs of the cast ZK60 etched samples immersed in $0.1 \mathrm{M} \mathrm{NaCl}$ for different times: (a,b) $1 \mathrm{~h}$ (with corrosion products); (c,d) $2 \mathrm{~h}$ (without corrosion products).

As shown in Figures 12 and 13, the etched samples were used to observe the origination and developmental features of the corrosion filaments on the cast ZK60. To avoid the influence of the etching treatment on the corrosion process, Figure 14 presents the secondary electron (SE) SEM images of the raw alloy sample after immersion in $0.1 \mathrm{M} \mathrm{NaCl}$ for 0.5 and $2 \mathrm{~h}$. The corrosion morphologies in Figure 14a,b also exhibit the characteristics of filiform corrosion, similar to those in Figure 12b. The polishing scratches on the surface of the test samples do not appear to influence the initiation and extension of the corrosion filaments, suggesting that they are controlled by the microstructure of the cast ZK60 alloy. When $t=2 \mathrm{~h}$, the corrosion images in Figure 14c,d display features similar to those in Figure $13 \mathrm{c}$ and some small corrosion pits occur in the corrosion areas, which may have been the result of the loss of the second phase-particles. The raw cast ZK60 sample also displayed the filiform corrosion features in the early corrosion period $(0-2 \mathrm{~h})$.

Figure 15 presents the secondary electron (SE) SEM images of the cast ZK60 alloy after immersion in $0.1 \mathrm{M} \mathrm{NaCl}$ for different times to observe the corrosion development over a long period (12-72 h). The corrosion filaments gradually extended to the whole surface of the test samples after $24 \mathrm{~h}$, and the number and depth of the corrosion pits increased with time. These results further prove that with increasing corrosion time, the corrosion of the cast ZK60 alloy can develop toward the central area of grains and toward the depth of the alloy matrix, which is discussed below. 

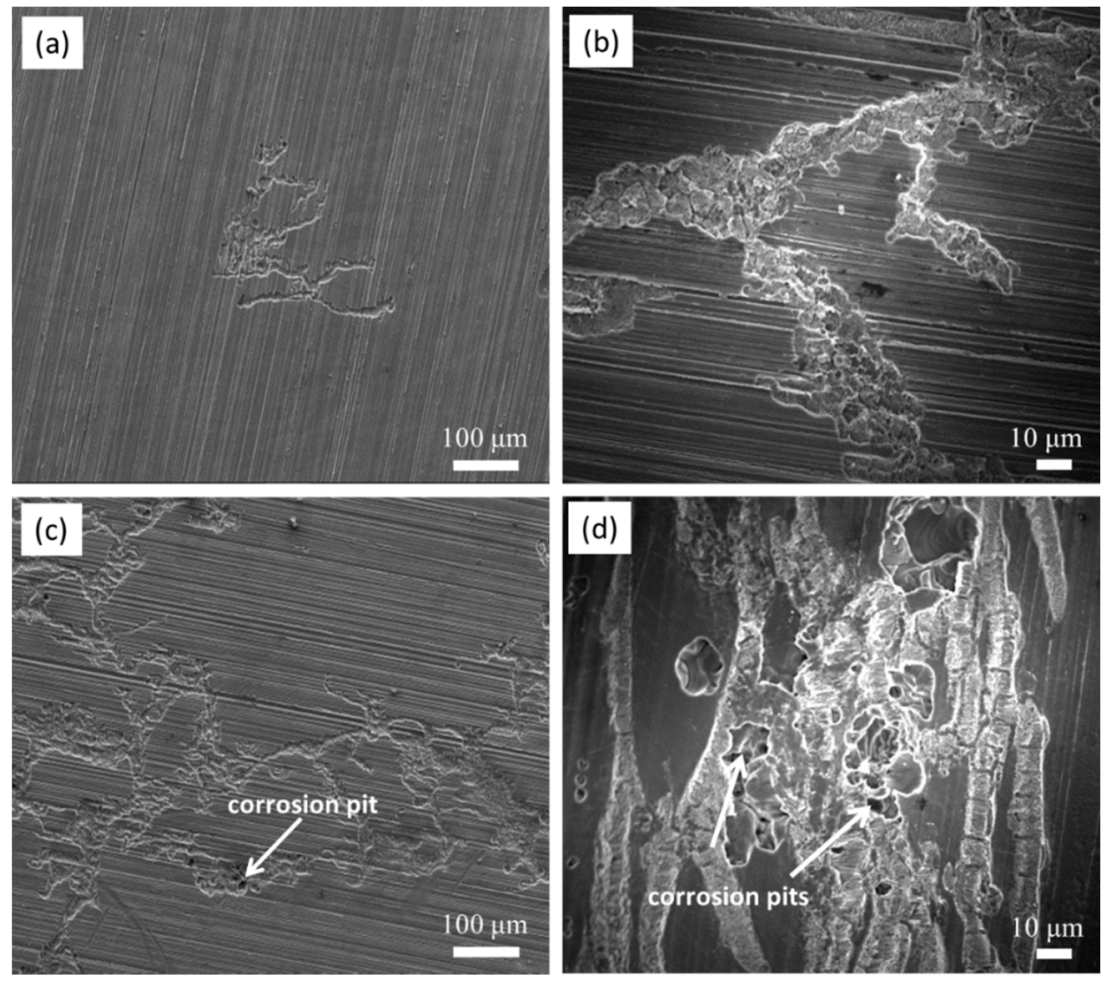

Figure 14. SE-SEM micrographs of the cast ZK60 sample immersed in $0.1 \mathrm{M} \mathrm{NaCl}$ for different times: (a,b) $30 \mathrm{~min}$; (c,d) $2 \mathrm{~h}$ (without corrosion products).
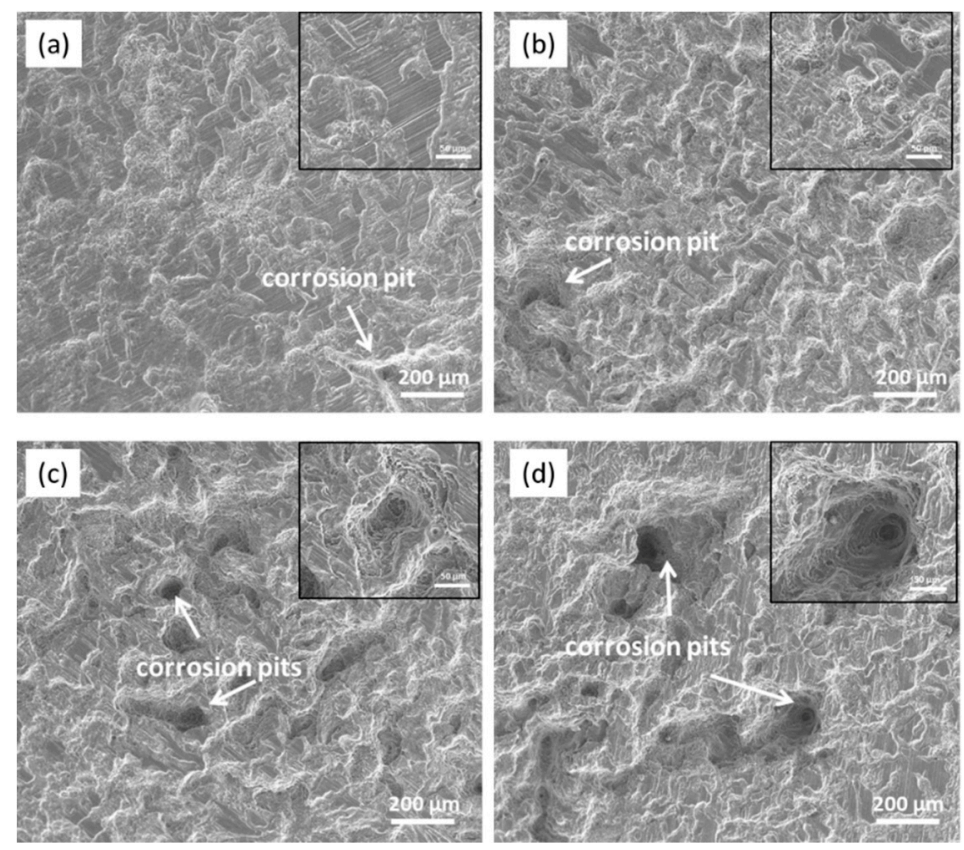

Figure 15. SE-SEM micrographs of the cast ZK60 alloy immersed in $0.1 \mathrm{M} \mathrm{NaCl}$ for different times: (a) $12 \mathrm{~h}$; (b) $24 \mathrm{~h}$; (c) $48 \mathrm{~h}$; (d) $72 \mathrm{~h}$ (with the corrosion products removed).

\subsection{Characterization of the Corrosion Pits on the Cast ZK60 Alloy}

To characterize the development of corrosion pits, the deepest pit on the cast ZK60 sample was selected after immersion in $0.1 \mathrm{M} \mathrm{NaCl}$ for different times, and their 3D morphologies and depth profiles were measured, as shown in Figure 16. The density and depth of the corrosion pits increased over $12-72 \mathrm{~h}$, and the size of the pit mouth was generally larger than the pit depth, which is similar 
to the corrosion morphologies in Figure 15. The corresponding pit depth at different corrosion times was employed to calculate the average penetration rate $\left(\mathrm{P}_{\mathrm{depth}}, \mathrm{mm} \mathrm{y}^{-1}\right)$, which is also presented in Figure 17. The pit depth increased with time, but the fastest $\mathrm{P}_{\text {depth }}$ occurred in the period of $12-24 \mathrm{~h}$ $\left(\sim 24 \mathrm{~mm} \mathrm{y}^{-1}\right)$ before gradually decreasing to $\sim 16.6 \mathrm{~mm} \mathrm{y}^{-1}$ in the period of $24-72 \mathrm{~h}$.
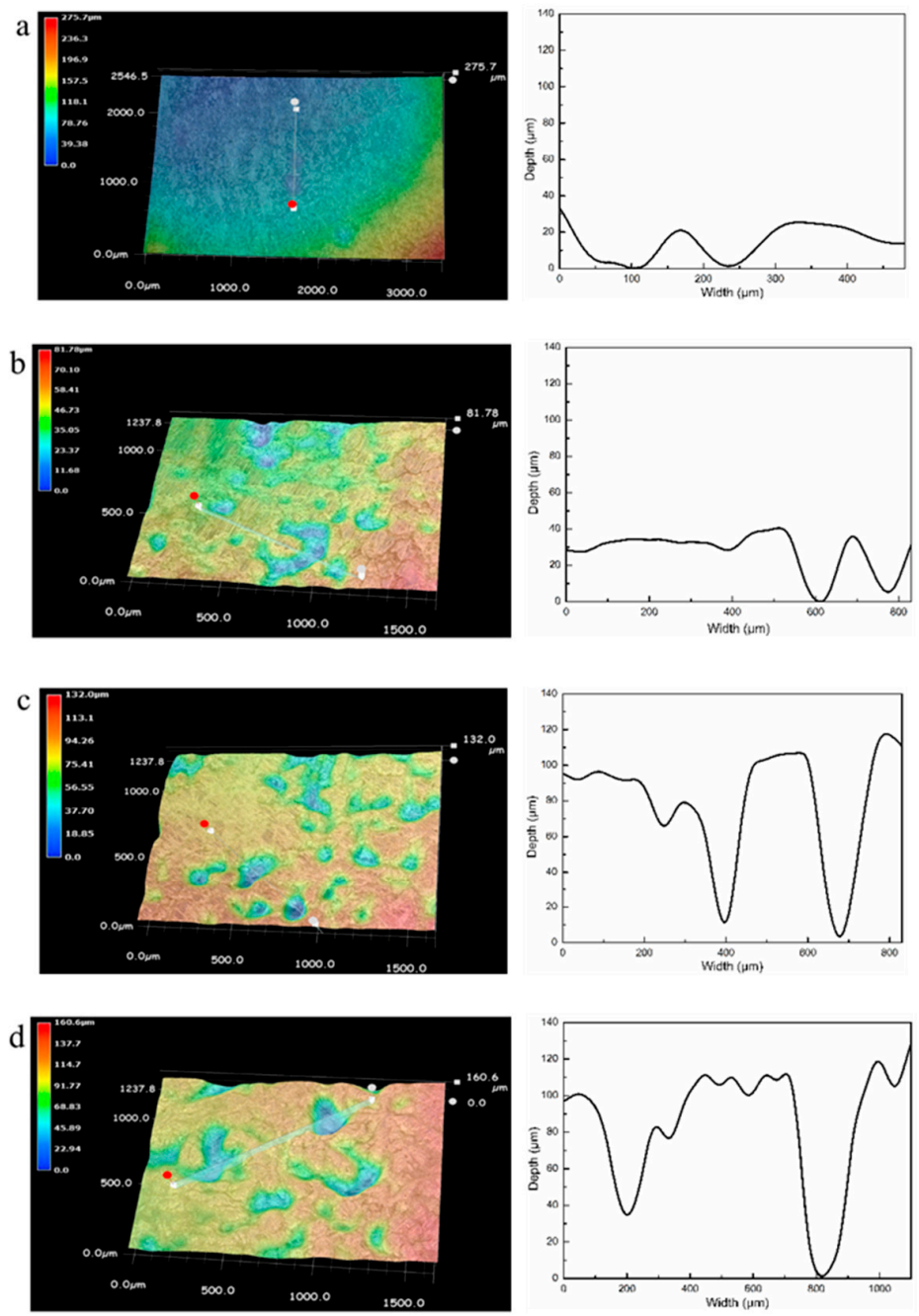

Figure 16. 3D corrosion images and depth profiles of the cast ZK60 alloy immersed in $0.1 \mathrm{M} \mathrm{NaCl}$ for different times: (a) $12 \mathrm{~h}$; (b) $24 \mathrm{~h}$; (c) $48 \mathrm{~h}$; (d) $72 \mathrm{~h}$ (without corrosion products).

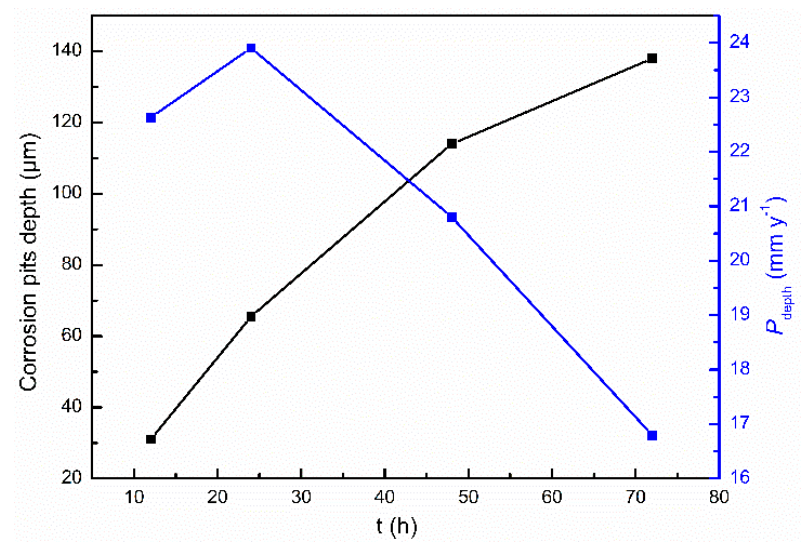

Figure 17. Depth of the deepest corrosion pit and the corresponding $P_{\text {depth }}$ of the cast ZK60 alloy immersed in $0.1 \mathrm{M} \mathrm{NaCl}$ for different times. 
Figure 18 is the cross-sectional EPMA pattern of a corrosion pit on the cast ZK60 sample immersed in $0.1 \mathrm{M} \mathrm{NaCl}$ for $72 \mathrm{~h}$. The corrosion pit was covered by the corrosion product, and the second-phase particles were encompassed in it. Only $\mathrm{Mg}, \mathrm{O}$, and $\mathrm{Cl}$ elements were found in the corrosion product layer, which should result from $\mathrm{Mg}(\mathrm{OH})_{2}$ and $\mathrm{Cl}^{-}$in the test solution. Moreover, a large number of $\mathrm{Cl}^{-}$through the whole corrosion product layer suggests that $\mathrm{Cl}^{-}$could penetrate the product layer easily and may become enriched in the bottom of the corrosion pit to propagate the pit corrosion [71]. The second-phase particles in the corrosion pit imply that they may be related to the formation of corrosion pits, which is discussed later.
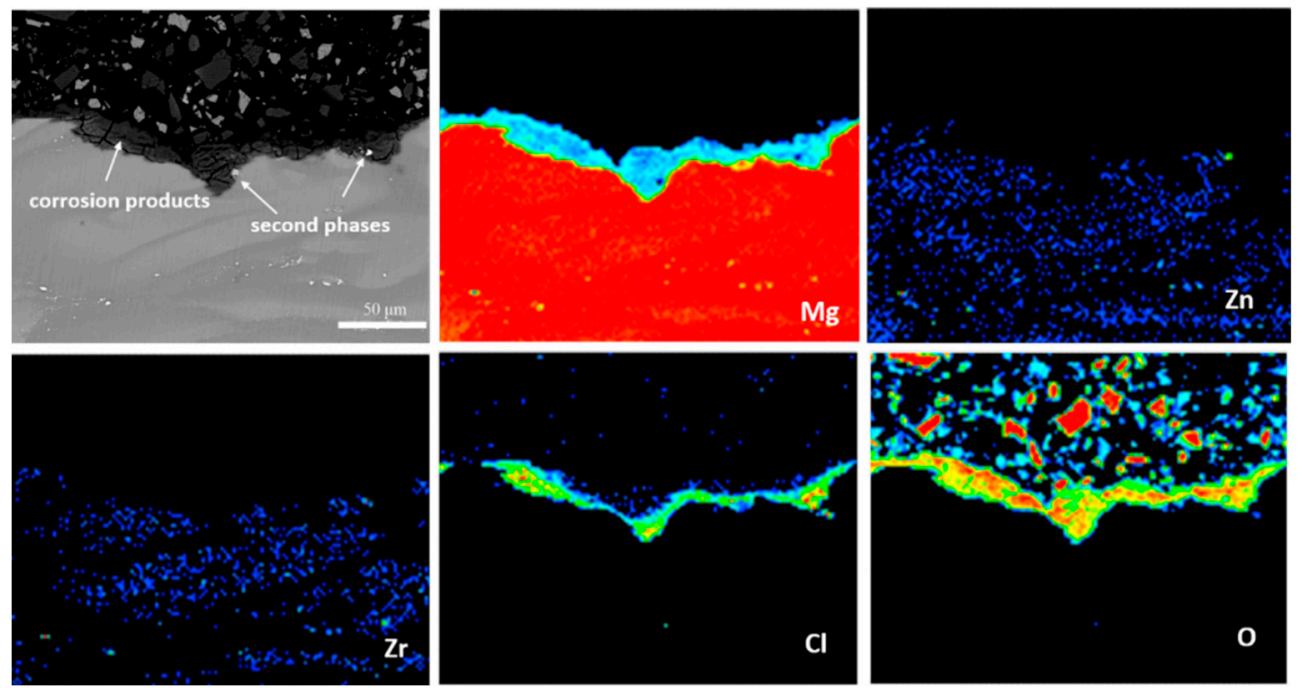

Figure 18. Electron probe micro-analyzer (EPMA) maps of the elemental distribution in the cross-section of a corrosion pit on the cast ZK60 alloy immersed in $0.1 \mathrm{M} \mathrm{NaCl}$ for $72 \mathrm{~h}$.

\section{Discussion}

\subsection{Initiation and Development of Corrosion on the Cast ZK60 Alloy}

\subsubsection{Corrosion Reactions on the Cast ZK60 Alloy}

A thin oxide film can be formed on the surface of the cast ZK60 alloy in a moist atmosphere at room temperature according to Reactions (5) and (6), which may have a bilayer structure with an inner layer of $\mathrm{MgO}$ and an outer layer of $\mathrm{Mg}(\mathrm{OH})_{2}[72,73]$.

$$
\begin{gathered}
2 \mathrm{Mg}+\mathrm{O}_{2}=2 \mathrm{MgO} \\
\mathrm{MgO}+\mathrm{H}_{2} \mathrm{O}=\mathrm{Mg}(\mathrm{OH})_{2}
\end{gathered}
$$

Because $\mathrm{MgO}$ and $\mathrm{Mg}(\mathrm{OH})_{2}$ are both relatively soluble in water according to Reactions (7) and (8) $[3,74]$, where $\mathrm{K}_{\mathrm{sp}}$ is the solubility product constant, $\mathrm{MgO}$ will be gradually dissolved and converted to $\mathrm{Mg}(\mathrm{OH})_{2}$ when they are immersed in $\mathrm{NaCl}$ solution.

$$
\begin{aligned}
& \mathrm{MgO}+\mathrm{H}_{2} \mathrm{O}=\mathrm{Mg}^{2+}+2 \mathrm{OH}^{-} K_{\mathrm{sp}}=10^{-6} \\
& \mathrm{Mg}(\mathrm{OH})_{2}=\mathrm{Mg}^{2+}+2 \mathrm{OH}^{-} \quad K_{\mathrm{sp}}=10^{-11}
\end{aligned}
$$

In this case, the $\mathrm{MgO} / \mathrm{Mg}(\mathrm{OH})_{2}$ oxide film formed on the cast $\mathrm{ZK} 60$ alloy was partly protective in a neutral $\mathrm{NaCl}$ solution. The anodic and cathodic partial reactions of the corrosion process can be written as Reactions (9) and (10), respectively, and the corrosion product is formed as Reaction (11) [75].

$$
\mathrm{Mg}=\mathrm{Mg}^{2+}+2 \mathrm{e}^{-}
$$




$$
\begin{gathered}
2 \mathrm{H}_{2} \mathrm{O}+2 \mathrm{e}^{-}=\mathrm{H}_{2}(\mathrm{~g})+2 \mathrm{OH}^{-} \\
\mathrm{Mg}^{2+}+2 \mathrm{OH}^{-}=\mathrm{Mg}(\mathrm{OH})_{2}
\end{gathered}
$$

\subsubsection{Initiation of Corrosion on the Cast ZK60 Alloy}

Based on the microstructure of the cast ZK60 alloy, Figure 19 presents a schematic model to illustrate the initiation and development of the corrosion on the cast ZK60 alloy. As discussed above, a partly protective $\mathrm{MgO} / \mathrm{Mg}(\mathrm{OH})_{2}$ oxide film will be formed on the cast ZK60 alloy in neutral $0.1 \mathrm{M}$ $\mathrm{NaCl}$ (Figure 19a). Because the large second-phase particles and the $\mathrm{Zr}$-rich region in the grains were more stable than the Mg matrix in grain boundary regions, as shown in Figure 6, the oxide film in these regions should be more stable than that in their adjacent grain boundary regions (i.e., darker areas in Figure 2b), which was denoted as a stable and active oxide film in Figure 19a $[76,77]$.

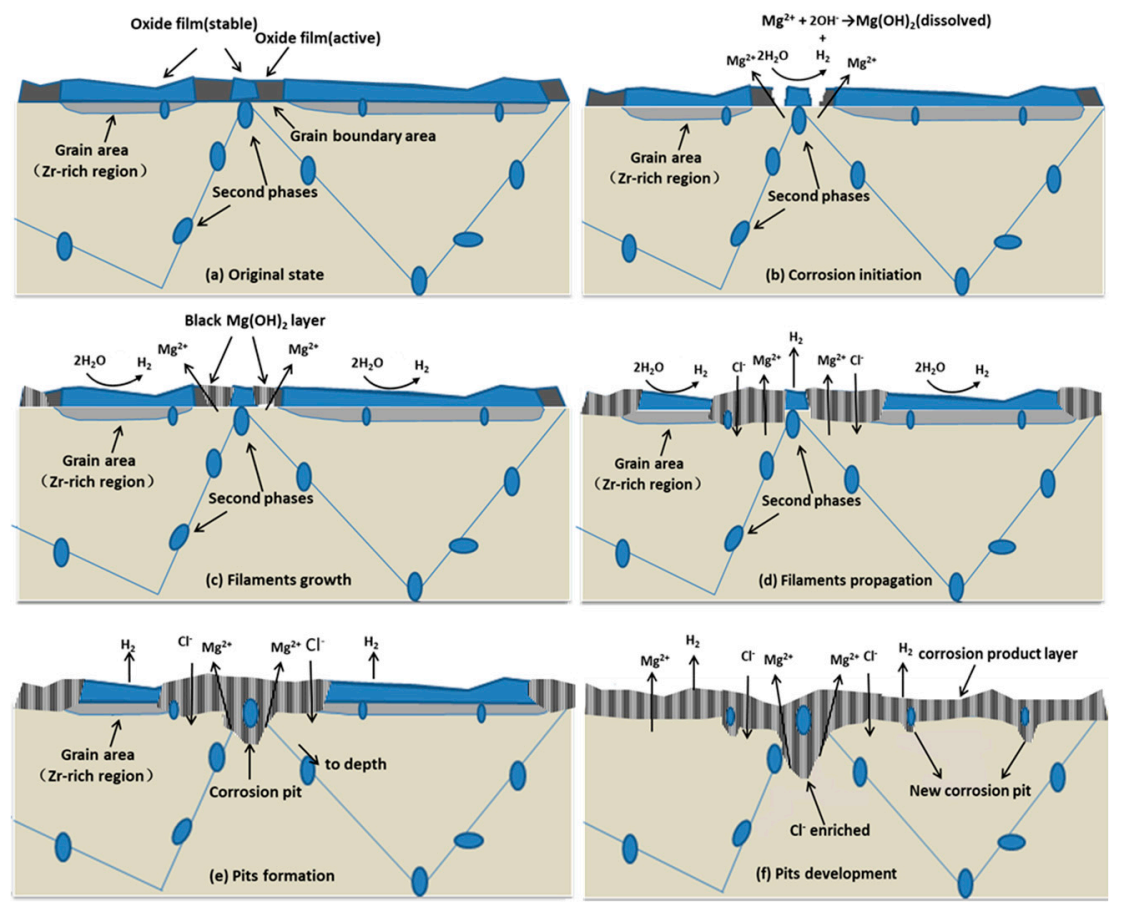

Figure 19. Schematic model for the initiation and development of the corrosion on the cast ZK60 alloy in $\mathrm{NaCl}$ solution. (a) original state; (b) corrosion initiation; (c) filaments growth; (d) filaments propagation; (e) pit formation and (f) pit development.

Compared to the $\mathrm{Mg}$ matrix in the grain boundary regions, those with stable oxide film act as micro-galvanic cathodes. Under the attack of $\mathrm{Cl}^{-}$, the film around the second phase could be easily broken due to the higher numbers of imperfections [78]. Therefore, the micro-galvanic corrosion was initiated in the areas around the large discontinuous second-phase particles in the grain boundaries, owing to the strong galvanic effect between these second-phase particles and the $\mathrm{Mg}$ matrix in the grain boundaries (Figure 13b). It should be noted that there were some second-phase particles deposited in the grains (Figures 2a and 6), and therefore, the corrosion may also be initiated in the grains. However, we did not observe this phenomenon, which may be due to the stable oxide film in the grains (Zr-rich region) and the light galvanic effect between them.

After the corrosion initiation (Figure 19b), the oxide film near the second-phase particles in the grain boundaries cracked first. However, there were no black $\mathrm{Mg}(\mathrm{OH})_{2}$ products observed in this beginning period (Figure 12a), because they were dissolved in the $\mathrm{NaCl}$ solution (Equation (5)). After the concentration of $\mathrm{Mg}(\mathrm{OH})_{2}$ reached saturation in the $\mathrm{NaCl}$ solution, black $\mathrm{Mg}(\mathrm{OH})_{2}$ precipitation occurred (Figure 12b). 


\subsubsection{Growth of Corrosion Filaments on the Cast ZK60 Alloy}

Because the Zr-rich area within the grains was more stable than the $\mathrm{Mg}$ matrix in grain boundary regions, the corrosion preferentially propagated in the grain boundary regions in the initial corrosion period (Figure 19c), displaying the characteristics of filiform-like corrosion, as shown in Figures 12 and 13. According to [69,70], the front edges of the corrosion filaments acted as intense anodes via Equation (6), while the dark tracks behind the anodes acted as locally activated cathodes, where cathodic Equation (7) occurred. In $\mathrm{NaCl}$ solution, $\mathrm{Cl}^{-}$may be enriched around the anode areas to attack and break the oxide film [28]. By contrast, the activated cathodes behind the anodes provide the driving force for the development of the corrosion filaments. Then, the precipitates of $\mathrm{Mg}(\mathrm{OH})_{2}$ cover the surface of the active cathodes behind the anodes to make them gradually turn into inert cathodes.

The second phase in the grain boundaries and the $\mathrm{Zr}$-rich region within the grains have an essential influence on the origination and propagation of the corrosion filaments on the cast ZK60. These filiform-like corrosion characteristics of the cast ZK60 were quite different from those of Mg-3Zn and $\mathrm{Mg}-8 \mathrm{Li}$ alloys reported previously [65,71], in which the corrosion filaments seem not to be affected by the second phases and can originate from the center of the grains and spread to various directions. These differences should be ascribed to their different microstructures, especially the quantity and size of the second phase and the distribution of alloying elements in these alloys.

As the corrosion time was increased, the active "dark areas" along the grain boundaries were gradually covered with a black $\mathrm{Mg}(\mathrm{OH})_{2}$ layer (Figure 19c) and potentially became cathodic areas [79]. This change would impede the anodic corrosion process in these areas and make their potential positive, reducing and even eliminating the potential difference between these areas and the $\mathrm{Zr}$-rich regions. Therefore, the corrosion filaments could gradually develop to the central area of grains (Figure 19d) to form some broad corrosion areas, as shown in Figures 13 and 14. Additionlly, the black $\mathrm{Mg}(\mathrm{OH})_{2}$ layer was porous and imperfect and could not prevent the entry of the $\mathrm{NaCl}$ solution (Figure 18). Thus, the anodic process still existed beneath the $\mathrm{Mg}(\mathrm{OH})_{2}$ layer, developing an apparent corrosion depth under the corrosion filaments, as shown in Figures 13 and 14 . When $t>24 \mathrm{~h}$, most of the alloy surface was gradually covered with the $\mathrm{Mg}(\mathrm{OH})_{2}$ layer (Figure 15), and finally, it would be covered completely (Figure 19e,f).

\subsubsection{Development of Corrosion Pits on the Cast ZK60 Alloy}

With the development of the corrosion filaments, the corrosion pits will be formed when the $\mathrm{Mg}$ matrix surrounding the large second-phase particles is corroded completely (Figure 19e). Some small corrosion pits occurred in the corrosion filaments when $\mathrm{t}=2 \mathrm{~h}$ (Figure 14c,d), which may be due to the loss of the second-phase particles when the corrosion product was removed. The visible corrosion pits occurred after $12 \mathrm{~h}$ of immersion (Figure 15), and their number and depth increased with time over 24-72 $\mathrm{h}$, in which $\mathrm{P}_{\text {depth }}$ was about one magnitude order higher than those corrosion rates $\left(\mathrm{P}_{\mathrm{w}}, \mathrm{P}_{\mathrm{H}}\right.$, and $\left.P_{i}\right)$, as shown in Figures 15-17. The high $P_{\text {depth }}$ of the cast ZK60 alloy indicates a severe localized corrosion state and warrants further investigation.

The development of the corrosion pits was related to the occluded environment under the corrosion filaments, covered by the second-phase particles and $\mathrm{Mg}(\mathrm{OH})_{2}$ precipitate. The solution in the occluded corrosion pit would be alkalized to increase the $\mathrm{pH}$ to around 10.5 through Reaction (5). At the same time, $\mathrm{Cl}^{-}$would migrate in due to the charge neutralization and become enriched at the bottom of the pit (Figure 18). These effects would accelerate the anodic process in the corrosion pits and make them develop deeply [80].

According to the above discussion, the microstructure of the cast ZK60 alloy had an essential influence on the corrosion initiation and propagation in $\mathrm{NaCl}$ solution. Thus, it is necessary to improve its corrosion resistance by microstructure modification, which will be studied later. 


\subsection{Change in the Corrosion Rate in Different Corrosion Periods}

The $P_{H}, P_{i}$, and $R_{p}$ values of the cast $Z K 60$ alloy generally showed different change tendencies in different immersion periods (Figures $8,9 \mathrm{~b}$ and $10 \mathrm{~b}$ ). In the early corrosion period $(0-2 \mathrm{~h}$ ), the corrosion rates $\left(P_{H}\right.$ and $\left.P_{i}\right)$ increased with time (Figures $8 b$ and $9 b$ ), while $R_{t}, R_{f}$, and $R_{p}$ decreased (Table 2 and Figure 10b). In this period, the filiform corrosion was initiated and developed quickly on the cast ZK60 alloy without visible corrosion pits (Figures 12-14), corresponding to the states in Figure 19a-d. In this case, with the development of the corrosion filaments, the broken oxide film increased steadily to accelerate the anodic and cathodic processes, as shown in Figure 9, and made the corrosion rates increase. The increase in the broken oxide film may be the reason why no $E_{\text {break }}$ occurred in the anodic polarization curve when $t=2 \mathrm{~h}$ (Figure 9). Furthermore, the increase in the broken oxide film enlarged the reactive areas on the cast $Z K 60$ surface to increase $C P E_{d l}$ and $C P E_{f}$, meanwhile decreasing $R_{L}$ and $\mathrm{L}$ in this period $(0-2 \mathrm{~h}$, Table 2$)$.

The second corrosion period was determined to be within 2-24 h, according to the above discussion about the corrosion development on the cast ZK60 alloy. In this period, the corrosion filaments gradually occupied most of the active oxide film, and a small number of corrosion pits occurred and developed quickly (Figures 15 and 16), which corresponds to the state in Figure 19e. Because most of the active oxide film was corroded and covered with a black $\mathrm{Mg}(\mathrm{OH})_{2}$ precipitate, the anodic process, Reaction (9), was inhibited significantly to make $\mathrm{E}_{\mathrm{corr}}$ more positive, and $\mathrm{E}_{\text {break }}$ occurs again with a more positive value (Figure 9). In this case, the corrosion rate $\left(P_{\mathrm{H}}\right.$ and $\left.\mathrm{P}_{\mathrm{i}}\right)$ decreased significantly (Figures $8 \mathrm{~b}$ and $9 \mathrm{~b}$ ), while $R_{t}, R_{f}$, and $R_{p}$ increased (Table 2 and Figure 10b). The difference is that $P_{i}$ and $1 / R_{p}$ reached the lowest value at $t=24 h$, but $P_{H}$ decreased persistently until $t=48 h$, while $P_{w}$ as shown in Figure 7 displayed the highest value at $t=24 \mathrm{~h}$, which may be ascribed to the differences among these test methods. In this period, the decrease in the broken oxide film may also result in a clear increase in $\mathrm{R}_{\mathrm{L}}$ and $\mathrm{L}$ and decrease in $\mathrm{CPE}_{\mathrm{dl}}$ (Table 2). Meanwhile, $\mathrm{CPE}_{\mathrm{f}}$ firstly increased and then decreased, which may have been due to the increase in the area and thickness of the corrosion product layer. Even though very few corrosion pits occurred in this period (Figures 15 and 16), their $\mathrm{P}_{\text {depth }}$ increased significantly and reached a large value of about $24 \mathrm{~mm} \mathrm{y}^{-1}$ (Figure 17), which was much larger than the general corrosion rates of $P_{\mathrm{w}}, \mathrm{P}_{\mathrm{H}}$, and $\mathrm{P}_{\mathrm{i}}$ in this period (Figures 7,8 and $9 \mathrm{~b}$ ). Therefore, the pitting corrosion became more critical than the filiform corrosion in this period.

Over 24-72 $\mathrm{h}$, most of the surface of the cast $\mathrm{ZK} 60$ was gradually covered with $\mathrm{Mg}(\mathrm{OH})_{2}$ layer, but the number and depth of the corrosion pits increased (Figures 15-17), corresponding to the state in Figure 19f. Because of the increase in corrosion pits, the anodic process was accelerated again. In this case, the $E_{\text {break }}$ and $E_{\text {corr }}$ of the cast ZK60 alloy became negative, and $P_{i}$ increased again (Figure 9), while $R_{t}, R_{f}$, and $R_{p}$ decreased (Table 2 and Figure 10b). However, $P_{w}$ and $P_{\text {depth }}$ decreased with time in this period (Figures 7 and 17), indicating that the increase in the corrosion product layer still impeded the growth rate of the pitting depth and the general weight loss, possibly due to the alkalizing effect of the cathodic reaction and the low solubility of $\mathrm{Mg}(\mathrm{OH})_{2}$. In this period, the increase in $\mathrm{CPE}_{\mathrm{f}}$ may have been due to the dissolution of the corrosion product layer reducing its thickness; meanwhile, the decrease in $R_{L}$ and $L$ may have been related to the acceleration of the pitting corrosion process, similar to in the processes on passive metals [61]. In general, pitting corrosion became more severe in this period and dominated the corrosion behavior of the cast ZK60 alloy. In this case, $P_{\text {depth }}$ should be adequate to describe the corrosion rate of the cast ZK60 alloy in this period.

\section{Conclusions}

1. The microstructure of the cast ZK60 alloy was composed of an $\alpha-\mathrm{Mg}$ phase and large second-phase particles $\left(\mathrm{MgZn}_{2}\right)$, which mainly deposited along the grain boundaries, and a Zr-rich region existed in the central area of the grains. The grain boundaries and their adjacent regions (noted as grain boundary regions) had relatively higher $\mathrm{Mg}$ contents. 
2. The second-phase particles and the central area of the grains (Zr-rich region) were more electrochemically stable than the grain boundary regions, resulting in a strong micro-galvanic effect between them.

3. The corrosion of the cast ZK60 alloy in $0.1 \mathrm{M} \mathrm{NaCl}$ solution originated from the areas around the second-phase particles in grain boundaries and firstly developed in the grain boundary regions, showing filiform-like corrosion characteristics owing to the strong micro-galvanic effect in its microstructure.

4. The general corrosion rate increased in the early corrosion period (about $0-2 \mathrm{~h}$ ). Then, the black corrosion filaments covered with $\mathrm{Mg}(\mathrm{OH})_{2}$ gradually occupied most of the alloy surface to inhibit the corrosion process and decrease its general corrosion rate. However, corrosion pits occurred under the corrosion filaments and had a high growth rate $\left(\mathrm{P}_{\mathrm{depth}}\right)$ in this period. After $24 \mathrm{~h}$, the number of corrosion pits increased, and $\mathrm{P}_{\text {depth }}$ decreased with time (17-24 $\left.\mathrm{mm} \mathrm{y}^{-1}\right)$ but was still eight times larger than the general corrosion rates $\left(\mathrm{P}_{\mathrm{w}}, \mathrm{P}_{\mathrm{H}}\right.$, and $\left.\mathrm{P}_{\mathrm{i}}\right)$, which should be paid more attention. The microstructure of the cast ZK60 alloy has an essential influence on the initiation and development of its corrosion.

Author Contributions: Conceptualization, Z.L. and Y.Q.; methodology, Z.L.; software, Z.L., Z.P. and K.Q.; validation, Y.Q., K.Q. and X.G.; formal analysis, Z.L.; investigation, Z.L.; resources, Z.L., Z.P. and H.L.; data curation, Z.L., Z.P., and H.L.; writing — original draft preparation, Z.L.; writing-review and editing, K.Q., Y.Q., and X.G.; visualization, Z.L.; supervision, Y.Q.; funding acquisition, Y.Q. All authors have read and agreed to the published version of the manuscript.

Funding: This research received no external funding.

Acknowledgments: The authors are thankful for the analysis support of the Key Laboratory of Material Chemistry for Energy Conversion and Storage and the Analytical and Testing Center, Huazhong University of Science and Technology.

Conflicts of Interest: The authors declare no conflict of interest.

\section{References}

1. Xu, T.C.; Yang, Y.; Peng, X.D.; Song, J.F.; Pan, F.S. Overview of advancement and development trend on magnesium alloy. J. Magnesium. Alloy 2019, 7, 536-544. [CrossRef]

2. Zhang, L.L.; Zhang, Y.T.; Zhang, J.S.; Zhao, R.; Zhang, J.X.; Xu, C.X. Effect of alloyed mo on mechanical properties, biocorrosion and cytocompatibility of as-cast Mg-Zn-Y-Mn alloys. Acta Metall. Sin. 2020, 33, 500-513. [CrossRef]

3. Esmaily, M.; Svensson, J.E.; Fajardo, S. Fundamentals and advances in magnesium alloy corrosion. Prog. Mater. Sci. 2017, 89, 92-193. [CrossRef]

4. You, S.H.; Huang, Y.D.; Kainer, K.U.; Hort, N. Recent research and developments on wrought magnesium alloys. J. Magnesium. Alloy 2017, 5, 239-253. [CrossRef]

5. Atrens, A.; Song, G.L. Review of recent developments in the field of magnesium corrosion. Adv. Eng. Mater. 2015, 17, 400-453. [CrossRef]

6. Song, G.L.; Atrens, A. Recent insights into the mechanism of magnesium corrosion and research suggestions. Adv. Eng. Mater. 2007, 9, 177-183. [CrossRef]

7. Mordike, B.L.; Ebert, T. Magnesium properties-applications-potential. Mater. Sci. Eng. A 2001, 302, 37-45. [CrossRef]

8. Sezer, N.; Evis, Z.; Kayhan, S.M.; Tahmasebifar, A.; Koç, M. Review of magnesium-based biomaterials and their applications. J. Magnesium. Alloy 2018, 6, 23-43. [CrossRef]

9. Bettles, C.; Gibson, M.A. Current wrought magnesium alloys: Strengths and weaknesses. JOM 2005, 57, 46-49. [CrossRef]

10. Dharmendra, C.; Rao, K.P.; Jain, M.K.; Prasad, Y.V.R.K. Role of loading direction on compressive deformation behavior of extruded ZK60 alloy plate in a wide range of temperature. J. Alloys Compd. 2018, 744, 289-300. [CrossRef] 
11. Torbati-Sarraf, S.A.; Sabbaghianrad, S.; Figueiredo, R.B.; Langdon, T.G. Orientation imaging microscopy and microhardness in a ZK60 magnesium alloy processed by high-pressure torsion. J. Alloys Compd. 2017, 712, 185-193. [CrossRef]

12. He, Y.B.; Pan, Q.L.; Qin, Y.J. Microstructure and mechanical properties of ZK60 alloy processed by two-step equal channel angular pressing. J. Alloys Compd. 2010, 492, 605-610. [CrossRef]

13. Yang, Y.; Wang, Z.; Jiang, L.H. Evolution of precipitates in ZK60 magnesium alloy during high strain rate deformation. J. Alloys Compd. 2017, 705, 566-571. [CrossRef]

14. Wang, C.; Luo, T.J.; Zhou, J.X.; Yang, Y.S. Effects of solution and quenching treatment on the residual stress in extruded ZK60 magnesium alloy. Mater. Sci. Eng. A 2018, 722, 14-19. [CrossRef]

15. Wang, W.; Zhang, W.C.; Chen, W.Z.; Cui, G.R.; Wang, E.D. Effect of initial texture on the bending behavior, microstructure and texture evolution of ZK60 magnesium alloy during the bending process. J. Alloys Compd. 2018, 737, 505-514. [CrossRef]

16. Liu, W.C.; Dong, J.; Zhang, P.; Yao, Z.Y.; Zhai, C.Q.; Ding, W.J. High cycle fatigue behavior of as-extruded ZK60 magnesium alloy. J. Mater. Sci. 2009, 44, 2916-2924. [CrossRef]

17. Lin, J.B.; Wang, Q.D.; Peng, L.M.; Roven, H.J. Microstructure and high tensile ductility of ZK60 magnesium alloy processed by cyclic extrusion and compression. J. Alloys Compd. 2009, 476, 441-445. [CrossRef]

18. Xia, K.D.; Pan, H.; Wang, T.L. Effect of $\mathrm{Ca} / \mathrm{P}$ ratio on the structural and corrosion properties of biomimetic Ca-P coatings on ZK60 magnesium alloy. Mater. Sci. Eng. C 2017, 72, 676-681. [CrossRef]

19. Chen, J.X.; Tan, L.L.; Yang, K. Effect of heat treatment on mechanical and biodegradable properties of an extruded ZK60 alloy. Biol. Mater. 2017, 2, 19-26. [CrossRef]

20. Cho, J.H.; Han, S.H.; Jeong, H.T.; Choi, S.H. The effect of aging on mechanical properties and texture evolution of ZK60 alloys during warm compression. J. Alloys Compd. 2018, 743, 553-563. [CrossRef]

21. Torbati-Sarraf, S.A.; Langdon, T.G. Properties of a ZK60 magnesium alloy processed by high-pressure torsion. J. Alloys Compd. 2014, 613, 357-363. [CrossRef]

22. He, Y.B.; Pan, Q.L.; Qin, Y.J.; Liu, X.Y.; Li, W.B. Microstructure and mechanical properties of ultrafine grain ZK60 alloy processed by equal channel angular pressing. J. Mater. Sci. 2010, 45, 1655-1662. [CrossRef]

23. Liu, Z.; Xin, R.L.; Wu, X.; Liu, D.J.; Liu, Q. Improvement in the strength of friction-stir-welded ZK60 alloys via post-weld compression and aging treatment. Mater. Sci. Eng. A 2018, 712, 493-501. [CrossRef]

24. Song, G.L.; Atrens, A. Understanding magnesium corrosion-A framework for improved alloy performance. Adv. Eng. Mater. 2010, 5, 837-858. [CrossRef]

25. Song, G.L.; Atrens, A.; Dargusch, M. Influence of microstructure on the corrosion of diecast AZ91D. Corros. Sci. 1998, 41, 249-273. [CrossRef]

26. Song, G.L.; Atrens, A.; St John, D.; Li, Z. Magnesium Alloys and Their Applications; Wiley-VCH: Weinheinm, Germany, 2000; pp. 426-431.

27. Lunder, O.; Lein, J.E.; Aune, T.K.; Nisancioglu, K. The role of $\mathrm{Mg}_{17} \mathrm{Al}_{12}$ phase in the corrosion of $\mathrm{Mg}$ alloy AZ91. Corrosion 1989, 45, 741-748. [CrossRef]

28. Lafront, A.M.; Zhang, W.; Jin, S.; Tremblay, R.; Dube, D.; Ghali, E. Pitting corrosion of AZ91D and AJ62x magnesium alloys in alkaline chloride medium using electrochemical techniques. Electrochim. Acta 2015, 51, 489-501. [CrossRef]

29. Hara, N.; Kobayashi, Y.; Kagaya, D.; Akao, N. Formation and breakdown of surface films on magnesium and its alloys in aqueous solutions. Corros. Sci. 2007, 49, 166-175. [CrossRef]

30. Choi, H.Y.; Kim, W.J. Effect of thermal treatment on the bio-corrosion and mechanical properties of ultrafine-grained ZK60 magnesium alloy. J. Mech. Behav. Biomed. Mater. 2014, 37, 307-322. [CrossRef]

31. Li, X.; Jiang, J.H.; Zhao, Y.H.; Ma, A.B.; Wen, D.J.; Zhu, Y.T. Effect of equal-channel angular pressing and aging on corrosion behavior of ZK60 Mg alloy. Trans. Nonferrous. Met. Soc. China 2015, 25, 3909-3920. [CrossRef]

32. Orlov, D.; Ralston, K.D.; Birbilis, N.; Estrin, Y. Enhanced corrosion resistance of Mg alloy ZK60 after processing by integrated extrusion and equal channel angular pressing. Acta Mater. 2011, 59, 6176-6186. [CrossRef]

33. Zengin, H.; Turen, Y.; Ahlatci, H.; Sun, Y. mechanical properties and corrosion behavior of as-cast Mg-Zn-Zr-(La) magnesium alloys. J. Mater. Eng. Perform. 2018, 27, 389-397. [CrossRef]

34. Baek, S.M.; Kim, B.; Park, S.S. Influence of intermetallic particles on the corrosion properties of extruded ZK60 Mg alloy containing Cu. Metals 2018, 8, 323. [CrossRef] 
35. Biancardi, O.V.; Rosa, V.L.; Abreu, L.B.; Tavares, A.P.R.; Corrêa, R.G.; Cavalcanti, P.H.; Napoleão, B.I.; Pereira, S.E. Corrosion behavior of as-cast ZK60 alloy modified with rare earth addition in sodium sulfate medium. Corros. Sci. 2019, 158. [CrossRef]

36. Zhang, T.T.; Cui, H.W.; Cui, X.L.; Zhao, E.T.; Feng, R.; Pan, Y.K. Investigations on microstructures, mechanical and corrosion properties of Mg-5.5Zn-0.8Zr alloys with Sm addition. Mater. Res. Express 2019, 6. [CrossRef]

37. Cheng, Y.L.; Qin, T.W.; Wang, H.M.; Zhang, Z. Comparison of corrosion behaviors of AZ31, AZ91, AM60 and ZK60 magnesium alloys. Trans. Nonferrous. Met. Soc. China 2009, 19, 517-524. [CrossRef]

38. Zeng, R.C.; Kainer, K.U.; Blawer, C.; Dietzel, W. Corrosion of an extruded magnesium alloy ZK60 component-The role of microstructural features. J. Alloys Compd. 2011, 509, 4462-4469. [CrossRef]

39. Xu, H.Y.; Diwu, J.T.; Liu, X.; Yang, Y.Q. Corrosion behavior of ZK60 magnesium alloy in sodium halide solutions. J. Chin. Soc. Corros. Prot. 2015, 35, 245-251.

40. Gu, X.N.; Li, N.; Zheng, Y.F.; Ruan, L.Q. In vitro degradation performance and biological response of a Mg-Zn-Zr alloy. Mater. Sci. Eng. B 2011, 176, 1778-1784. [CrossRef]

41. Huan, Z.G.; Leeflang, M.A.; Zhou, J.; Fratila-Apachitei, L.E.; Duszczyk, J. In vitro degradation behavior and cytocompatibility of Mg-Zn-Zr alloys. J. Mater. Sci. Mater. Med. 2010, 21, 2623-2635. [CrossRef]

42. Zhang, S.Y.; Bi, Y.Z.; Li, J.Y.; Wang, Z.G.; Yan, J.M.; Song, J.W.; Sheng, H.B.; Guo, H.Q.; Li, Y. Biodegradation behavior of magnesium and ZK60 alloy in artificial urine and rat models. Biol. Mater. 2017, 2, 53-62. [CrossRef] [PubMed]

43. Jamesh, M.I.; Wu, G.S.; Zhao, Y.; McKenzie, D.R.; Bilek, M.M.M.; Chu, P.K. Electrochemical corrosion behavior of biodegradable $\mathrm{Mg}-\mathrm{Y}-\mathrm{RE}$ and $\mathrm{Mg}-\mathrm{Zn}-\mathrm{Zr}$ alloys in ringer's solution and simulated body fluid. Corros. Sci. 2015, 91, 160-184. [CrossRef]

44. Shi, Z.M.; Liu, M.; Atrens, A. Measurement of the corrosion rate of magnesium alloys using tafel extrapolation. Corros. Sci. 2010, 52, 579-588. [CrossRef]

45. Zhao, M.C.; Schmutz, P.; Brunner, S.; Liu, M.; Song, G.L.; Atrens, A. An exploratory study of the corrosion of $\mathrm{Mg}$ alloys during interrupted salt spray testing. Corros. Sci. 2009, 51, 1277-1292. [CrossRef]

46. Shi, Z.M.; Atrens, A. An innovative specimen configuration for the study of Mg corrosion. Corros. Sci. 2011, 53, 226-246. [CrossRef]

47. Wei, L.Y.; Dunlop, G.L.; Westengen, H. The intergranular microstructure of cast Mg-Zn and Mg-Zn-Rare earth alloys. Metall. Mater. Trans. 1995, 26, 1947-1955. [CrossRef]

48. Pan, F.S.; Mao, J.J.; Chen, X.H.; Peng, J.; Wang, J.F. Influence of impurities on microstructure and mechanical properties of ZK60 magnesium alloy. Trans. Nonferrous. Met. Soc. China 2010, 20, 1299-1304. [CrossRef]

49. He, Y.B.; Pan, Q.L.; Qin, Y.J. Effect of heat treatment on microstructure and mechanical properties of wrought ZK60 magnesium alloy. Heat Treat. Met. 2011, 36, 52-57.

50. Song, Y.W.; Shan, D.Y.; Chen, R.S.; Han, E.H. Effect of second phases on the corrosion behaviour of wrought Mg-Zn-Y-Zr alloy. Corros. Sci. 2010, 52, 1830-1837. [CrossRef]

51. Song, G.L. Corrosion Protection of Magnesium Alloys; Chemical Industry Press: Beijing, China, 2006.

52. Merson, D.; Vasiliev, E.; Markushev, M.; Vinogradov, A. On the corrosion of ZK60 magnesium alloy after severe plastic deformation. Lett. Mater. 2017, 7, 421-427. [CrossRef]

53. Cao, F.Y.; Shi, Z.M.; Hofstetter, J.; Uggowitzer, P.J.; Song, G.L.; Liu, M.; Atrens, A. Corrosion of ultra-high-purity $\mathrm{Mg}$ in 3.5\% $\mathrm{NaCl}$ solution saturated with $\mathrm{Mg}(\mathrm{OH})_{2}$. Corros. Sci. 2013, 75, 78-99. [CrossRef]

54. Sarraf, H.T.; Sarraf, S.A.T.; Poursaee, A.; Langdon, T.G. Electrochemical behavior of a magnesium ZK60 alloy processed by high-pressure torsion. Corros. Sci. 2019, 154, 90-100. [CrossRef]

55. Song, G.L. Recent progress in corrosion and protection of magnesium alloys. Adv. Eng. Mater. 2005, 7, 563-587. [CrossRef]

56. Song, G.L.; Unocic, K.A. The anodic surface film and hydrogen evolution on Mg. Corros. Sci. 2015, 9, 758-765. [CrossRef]

57. Song, Y.W.; Shan, D.Y.; Chen, R.S.; Han, E.H. Investigation of surface oxide film on magnesium lithium alloy. J. Alloys Compd. 2009, 29, 1039-1045. [CrossRef]

58. Gandel, D.S.; Easton, M.A.; Gibson, M.A.; Abbott, T.; Birbilis, N. The influence of zirconium additions on the corrosion of magnesium. Corros. Sci. 2014, 81, 27-35. [CrossRef]

59. King, A.D.; Birbilisa, N.; Scully, J.R. Accurate electrochemical measurement of magnesium corrosion rates; A combined impedance, mass-loss and hydrogen collection study. Electrochim. Acta 2014, 121, 394-406. [CrossRef] 
60. Liu, W.J.; Cao, F.H.; Chen, A.N.; Chang, L.R.; Zhang, J.Q.; Cao, C.N. Corrosion behaviour of AM60 magnesium alloys containing Ce or La under thin electrolyte layers. Part 1: Microstructural characterization and electrochemical behaviour. Corros. Sci. 2010, 52, 627-638. [CrossRef]

61. Cao, C.N.; Zhang, J.Q. An Introduction of Electrochemical Impedance Spectroscopy; Science Press: Beijing, China, 2002.

62. Song, G.L.; Atrens, A.; John, D.S.; Wu, X.; Nairn, J. The anodic dissolution of magnesium in chloride and sulphate solutions. Corros. Sci. 1997, 39, 1981-2004. [CrossRef]

63. Song, Y.W.; Han, E.H. The effect of Zn concentration on the corrosion behavior of Mg-xZn alloys. Corros. Sci. 2012, 65, 322-330. [CrossRef]

64. Baril, G.; Galicia, G.; Deslouis, C.; Pebere, N.; Tribollet, B.; Vivier, V. An impedance investigation of the mechanism of pure magnesium corrosion in sodium sulfate solutions. J. Electrochem. Soc. 2007, 154, 108-113. [CrossRef]

65. Song, Y.W.; Han, E.H.; Shan, D.Y. Corrosion characterization of Mg-8Li alloy in NaCl solution. Corros. Sci. 2009, 51, 1087-1094. [CrossRef]

66. Shi, Z.M.; Cao, F.Y.; Song, G.L.; Atrens, A. Low apparent valence of Mg during corrosion. Corros. Sci. 2014, 88, 434-443. [CrossRef]

67. Gomes, M.P.; Costa, I.; Pebere, N.; Rossi, J.L.; Tribollet, B.; Vivier, V. On the corrosion mechanism of Mg investigated by electrochemical impedance spectroscopy. Electrochim. Acta 2019, 306, 61-70. [CrossRef]

68. Jönsson, M.; Persson, D.; Thierry, D. Corrosion product formation during $\mathrm{NaCl}$ induced atmospheric corrosion of magnesium alloy AZ91D. Corros. Sci. 2007, 49, 1540-1558. [CrossRef]

69. Williams, G.; Dafydd, H.L.; Grace, R. The localised corrosion of Mg alloy AZ31 in chloride containing electrolyte studied by a scanning vibrating electrode technique. Electrochim. Acta 2013, 109, 489-501. [CrossRef]

70. Williams, G.; Grace, R. Chloride-induced filiform corrosion of organic-coated magnesium. Electrochim. Acta 2011, 56, 1894-1903. [CrossRef]

71. Wang, H.X.; Song, Y.W.; Yu, J.; Shan, D.Y.; Han, E.H. Characterization of filiform corrosion of Mg-3Zn Mg Alloy. J. Electrochem. Soc. 2017, 1649, 574-580. [CrossRef]

72. Atrens, A.; Song, G.L.; Shi, Z.M.; Soltan, A.; Johnston, S.; Dargusch, M.S. Understanding the corrosion of Mg and Mg alloys. Encycl. Interfacial Chem. 2018, 515-534.

73. Song, Y.W.; Han, E.H.; Shan, D.Y.; Yim, C.D.; You, B.S. Microstructure and protection characteristics of the naturally formed oxide films on Mg-x Zn alloys. Corros. Sci. 2013, 72, 133-143. [CrossRef]

74. Nordlien, J.H.; Ono, S.; Masuko, N.; Nisancioglu, K. Morphology and structure of oxide films formed on magnesium by exposure to air and water. J. Electrochem. Soc. 1995, 142, 3320-3322. [CrossRef]

75. Dinodi, N.; Shetty, A.N. Electrochemical investigations on the corrosion behaviour of magnesium alloy ZE41 in a combined medium of chloride and sulphate. J. Magnesium. Alloys 2013, 1, 201-209. [CrossRef]

76. Kaya, A.; Ben-Hamu, G.; Eliezer, D.; Shin, K.S.; Cohen, S. Corrosion and oxidation of alloys of the Mg-Y-Zr-REM system. Met. Sci. Heat. Treat. 2006, 48, 518-523. [CrossRef]

77. Ben-Hamu, G.; Eliezer, D.; Shin, K.S.; Cohen, S. The relation between microstructure and corrosion behavior of Mg-Y-RE-Zr alloys. J. Alloys Compd. 2007, 431, 269-276. [CrossRef]

78. Lindström, R.; Johansson, L.G.; Thompson, G.E.; Skeldon, P.; Svensson, J.E. Corrosion of magnesium in humid air. Corros. Sci. 2004, 46, 1141-1158. [CrossRef]

79. Song, G.L.; Atrens, A. Corrosion mechanisms of magnesium alloys. Adv. Eng. Mater. 1999, 1, 11-33. [CrossRef]

80. Zeng, R.C.; Zhang, J.; Huang, W.J.; Kainer, K.U.; Blawer, C.; Dietzel, W.; Ke, W. Review of studies on corrosion of magnesium alloys. Trans. Nonferrous. Met. Soc. China 2006, 16, 763-771. [CrossRef]

(C) 2020 by the authors. Licensee MDPI, Basel, Switzerland. This article is an open access article distributed under the terms and conditions of the Creative Commons Attribution (CC BY) license (http://creativecommons.org/licenses/by/4.0/). 